The Canadian Mineralogist

Vol. 38, pp. 191-216 (2000)

\title{
HIGH-Mg ARC-ANKARAMITIC DIKES, GREENHILLS COMPLEX, SOUTHLAND, NEW ZEALAND
}

\author{
DAVID J. MOSSMAN $\$$ \\ Department of Physics, Engineering and Geoscience, Mount Allison University, Sackville, New Brunswick E4L 1E6, Canada \\ DOUGLAS S. COOMBS, YOSUKE KAWACHI* AND ANTHONY REAY \\ Department of Geology, University of Otago, Dunedin, New Zealand
}

\begin{abstract}
Minor dikes 8-70 cm thick of ankaramitic composition were emplaced late in the crystallization of the Greenhills Complex, a layered dunite - wehrlite - hornblende gabbronorite intrusion of Permian age in the volcanic arc-derived Brook Street Terrane of southern New Zealand. Mg contents range from 10 to $28 \mathrm{wt} \% \mathrm{MgO}$. The interior of a hornblende ankaramite dike at Steep Head contains phenocrysts of olivine $\mathrm{Fo}_{93-82}$, in some cases skeletal, and scattered phenocrysts of diopside, set in a groundmass of magnesiohornblende. The chilled margins of this dike consist almost wholly of amphibole (91\%) and anorthite, An ${ }_{99-94}(9 \%)$. In other dikes, crystallization of amphibole followed that of olivine, diopside, enstatite, and overlapped with plagioclase. Olivine in these dikes varies in composition from $\mathrm{FO}_{90}$ to $\mathrm{Fo}_{72}$. Diopside contains oriented blebs of magnesiohornblende and edenite. We believe that the components of these amphibole inclusions were in part introduced and in part derived from the host pyroxene by a process of reactive exsolution. Spinel varies from chromite containing $53 \mathrm{wt} \% \mathrm{Cr}_{2} \mathrm{O}_{3}$ through compositions at first increasingly Al-rich, and then through chromian magnetite to virtually $\mathrm{Cr}$-free magnetite. Amphiboles range from magnesiohornblende to edenite, pargasite, and tschermakite, with minor late-stage high-Si magnesiohornblende. The aphyric margin of the Steep Head dike contains $17.4 \mathrm{wt} \% \mathrm{MgO}$ on a volatile-free basis. Some of the melts may have exceeded this $\mathrm{MgO}$ content. Dike centers are more $\mathrm{Mg}$-rich than margins, reaching $28.3 \%$ in one case, in part an effect of concentration of phenocrysts by flow differentiation, and in part a result of changing composition of the melt. The presence of abundant magmatic amphibole, especially in the most magnesian rocks, indicates a relatively hydrous magma. Various geothermometers suggest extensive low-temperature re-equilibration. Even where the dikes consist of almost monomineralic amphibole, chemically they are arc-ankaramites with $\mathrm{CaO} / \mathrm{Al}_{2} \mathrm{O}_{3}$ $>1$, REE contents less than twice primitive mantle, low abundances of high-field-strength elements and of incompatible elements, highly calcic plagioclase, and $\mathrm{Cr}$-rich spinels with $\mathrm{Ti}, \mathrm{Mg}$, and $\mathrm{Cr}$ contents typical of low- $\mathrm{K}$, high-Mg ankaramitic arc-tholeiitic suites. They have some chemical similarities to komatiites, but have lower $\mathrm{Ni} / \mathrm{MgO}, \mathrm{Cr} / \mathrm{MgO}$, and $\mathrm{Ti} / \mathrm{V}$ values. The most highly magnesian dike-rocks have olivine in excess of diopside, whereas in dikes with lower $\mathrm{Mg}$ contents, the proportion of diopside phenocrysts exceeds that of olivine. Progressive fractionation of these two minerals lowered the bulk $\mathrm{CaO} / \mathrm{Al}_{2} \mathrm{O}_{3}$ ratio. $\mathrm{Below}$ about $10 \% \mathrm{MgO}, \mathrm{CaO} / \mathrm{Al}_{2} \mathrm{O}_{3}$ was no longer greater than one, the ankaramitic nature was lost, and evolution continued along an arc-tholeiitic trend. The dike compositions support the hypothesis that the Greenhills Complex is the remnant of an upper-crust magma chamber from which arc-ankaramites, tholeiitic basalts, and more evolved effusive volcanic products in the Brook Street Terrane were erupted. The highly magnesian ankaramitic dikes and their effusive analogues provide another example of an association increasingly recognized in Phanerozoic island-arc systems.
\end{abstract}

Keywords: Greenhills Complex, Brook Street Terrane, ankaramite, flow differentiation, olivine, clinopyroxene, chromite, amphibole, arc volcanism, reactive exsolution, New Zealand.

\section{SOMMAIRE}

De petits filons, de 8 à $70 \mathrm{~cm}$ d'épaisseur et de composition ankaramitique, ont été mis en place tardivement au cours de la cristallisation du complexe de Greenhills, massif stratiforme intrusif de dunite - wehrlite - gabbronorite à hornblende d'âge permien lié au cortège volcanique appelé Brook Street Terrane, dans le sud de la Nouvelle-Zélande. Les teneurs en magnésium vont de 10 à 28\% $\mathrm{MgO}$ (en poids). L'intérieur d'un filon d'ankaramite à hornblende à Steep Head contient des phénocristaux d'olivine Fo93-82, dans certains cas squelettiques, et des phénocristaux épars de diopside, dans une pâte de magnésiohornblende. Les bordures figées de ce filon contiennent presqu'entièrement de l'amphibole (91\%) et de l'anorthite, An99-94 (9\%). Dans d'autres filons, l'amphibole a suivi l'olivine, le diopside et l'enstatite, et a co-cristallisé avec le plagioclase. L'olivine de ces filons

E-mail address: dmossman@mta.ca

* Present address: Research Centre for Mineral Resources Exploration, A-11 Datun Road, Beijing 100101, People's Republic of China. 
varie en composition de $\mathrm{FO}_{90}$ à $\mathrm{FO}_{72}$. Le diopside contient des microdomaines de magnésiohornblende et d'édenite. A notre avis, les composants de ces inclusions d'amphibole ont été introduits en partie, et d'autre part dérivés du pyroxène hôte par un processus d'exsolution réactionnelle. Le spinelle varie de chromite contenant 53\% de $\mathrm{Cr}_{2} \mathrm{O}_{3}$ (en poids) vers des compositions montrant d'abord une augmentation en aluminium, et ensuite une tendance vers la magnétite chromifère, pour aboutir à la magnétite presque sans Cr. La composition des amphiboles varie de magnésiohornblende à édenite, pargasite, et tschermakite, avec une tendance tardive vers des compositions plus siliceuses de magnésiohornblende. La bordure aphyrique du filon de Steep Head contient $17.4 \%$ de $\mathrm{MgO}$ sur une base anhydre. Certaines des venues magmatiques ont même peut-être dépassé cette teneur en $\mathrm{Mg}$. Le centre des filons contient davantage de Mg, jusqu'à $28.3 \%$ dans un cas, en partie à cause de l'effet de concentration de traînées de phénocristaux en flux, et d'autre part de l'évolution de la composition du magma. La présence d'une abondance d'amphibole magmatique, en particulier dans les roches les plus magnésiennes, indiquerait un magma relativement hydraté. Une batterie de géothermomètres indiquent l'importance de ré-équilibrage à faible température. Même dans le cas de filons contenant presqu' uniquement de l'amphibole, la composition chimique est celle d'ankaramites d'un milieu d' $\operatorname{arc}, \operatorname{avec} \mathrm{CaO} / \mathrm{Al}_{2} \mathrm{O}_{3}>1, \mathrm{la}$ concentration des terres rares moins que deux fois les teneurs chondritiques, de faibles teneurs en éléments à potentiel ionique élevé et en éléments incompatibles, un plagioclase à teneur en calcium très élevé, et un spinelle chromifère typique des suites tholéiitiques d'arc et ankaramitiques, avec teneurs faibles en $\mathrm{K}$ et élevées en $\mathrm{Mg}$. Ces roches partagent certaines des caractéristiques des suites komatiitiques, mais elles possèdent des valeurs des rapports $\mathrm{Ni} / \mathrm{MgO}, \mathrm{Cr} / \mathrm{MgO}$, et Ti/V plus faibles. Le filon qui contient la roche la plus magnésienne a plus d'olivine que de diopside, tandis que dans les filons moins magnésiens, la proportion de phénocristaux de diopside dépasse celle des phénocristaux d'olivine. Un fractionnement de ces deux minéraux a abaissé la valeur globale du rapport $\mathrm{CaO} / \mathrm{Al}_{2} \mathrm{O}_{3}$. Au dessous d'environ $10 \% \mathrm{MgO}$, le rapport $\mathrm{CaO} / \mathrm{Al}_{2} \mathrm{O}_{3}$ est passé à une valeur inférieure à l'unité, la filiation ankaramitique était perdue, et l'évolution a continué selon la lignée d'un système tholéiitique en milieu d'arc. La composition des filons étaye l'hypothèse voulant que le complexe de Greenhills est un lambeau d'une chambre magmatique sise à faible profondeur, dans laquelle des venues d'ankaramites d'arc, de basaltes tholéiitiques, et de produits effusifs plus évolués du cortège de Brook Street Terrane ont été mis en place. Les filons d'ankaramite magnésienne et leurs analogues effusifs fournissent un nouvel exemple d'une association qui semble devenir de plus en plus répandue dans les systèmes d'arcs insulaires phanérozoïques.

(Traduit par la Rédaction)

Mots-clés: complexe de Greenhills, cortège de Brook Street Terrane, ankaramite, différenciation par écoulement, olivine, clinopyroxène, chromite, amphibole, volcanisme d'arc, exsolution réactionnelle, Nouvelle-Zélande.

\section{INTRODUCTION}

The mafic to ultramafic Greenhills Complex (Fig. 1) of Bluff Peninsula, in Southland, New Zealand (Mossman 1973) occurs in the volcanic-arc-derived Brook Street Terrane (Frost \& Coombs 1989). It is interpreted as the crustal root of an intra-oceanic islandarc volcano that intruded thick, arc-flank sedimentary rocks dated as probably Artinskian to Kungurian, late Early Permian (Mossman \& Force 1969). Zircon from hornblende gabbronorite within the complex has yielded a uranium-lead age of $265 \mathrm{Ma}$ (Kimbrough et al. 1992); this is not measurably different from the inferred age of the intruded sedimentary rocks. Adjacent to the Complex and to associated bodies of hornblende gabbronorite (e.g., Service 1937), the sedimentary rocks are metamorphosed to pyroxene hornfels and hornblende hornfels. In the outer parts of the aureole, fine sedimentary and biogenic detail is preserved (Mossman \& Force 1969), and the metamorphic grade is inferred to have been no higher than greenschist facies. Corresponding sedimentary rocks in the upper part of the Takitimu Group, $85 \mathrm{~km}$ to the northwest, have experienced only very low grade alteration in the zeolite facies (Houghton 1982). Such evidence indicates that the Complex was emplaced at a high level in the crust.

Mossman (1973) described a layered series of dunite, wehrlite, and gabbro with highly calcic plagioclase,
$\mathrm{An}_{88-91}$. Late-stage trondhjemite dikes also occur. As now exposed, the body appears to have been disrupted into two crudely bowl-shaped parts. In contrast to early dikes, which include very coarse-grained gabbro (Mossman 1970, 1973), volumetrically minor late-stage high-Mg dikes are chilled. The margins of some of these are composed almost entirely of fine-grained hornblende and minor anorthite, which are possible products of quenching. Olivine and clinopyroxene phenocrysts in the high-Mg dikes vary greatly in relative proportion and, in some cases, show evidence of flowage differentiation. Matrices range from monomineralic pale greenish hornblende to medium-grained plagioclase orthopyroxene - clinopyroxene plus subordinate magmatic brownish and later-stage greenish hornblende and minor tremolite or actinolite.

The high-Mg dikes are interpreted as having formed from evolving, relatively hydrous liquids that initially contained up to at least $17 \% \mathrm{MgO}$. Whether or not the interior of the magma chamber was still fluid when they were emplaced is unclear, although the fact that such dikes have not been found in the central parts of the intrusion suggests that this was the case ( $c f$. Greenwood \& Donaldson 1989) and that they contributed to the magma pool or were derived from it.

Contents of up to $28.3 \% \mathrm{MgO}$ in olivine-rich dike interiors invite comparison with komatiites, whereas the clinopyroxene-rich nature of some of the dikes suggests 


\section{GREENHILLS MAFIC \& ULTRAMAFIC COMPLEX}
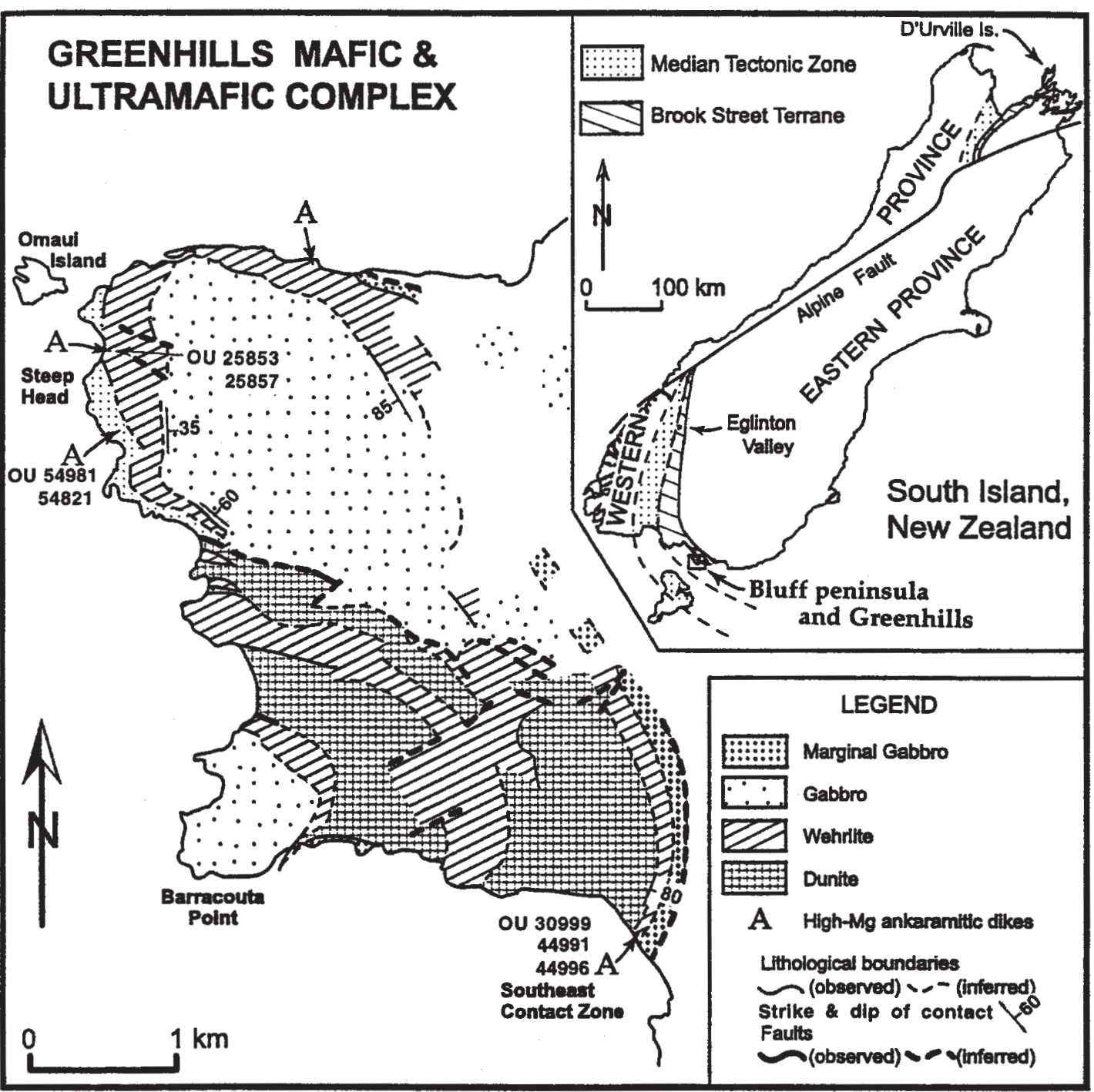

FIG. 1. Greenhills Complex, Bluff Peninsula, Southland, New Zealand (Mossman 1973) showing localities for ankaramitic dikes. Inset: locality map, South Island of New Zealand showing situation of Bluff Peninsula and other localities within the Brook Street Terrane, and the relationship of this terrane to the Median Tectonic Zone (Kimbrough et al. 1993), Eastern and Western Provinces, and the Alpine Fault.

a relationship to the ankaramites of island-arc settings. The dikes described here were identified by Mossman (1973) as picrites, but the ratio of $\mathrm{CaO}$ to $\mathrm{Al}_{2} \mathrm{O}_{3}$ is consistently greater than one, a feature used by DellaPasqua \& Varne (1997) to distinguish primitive arc-ankaramite from picrite. Although very minor in volume, the dikes provide evidence for an association of ankaramitic magma with cumulate wehrlite in an intrusive complex in an arc setting. Ankaramites are usually considered to contain abundant phenocrysts of clinopyroxene and olivine, but on grounds of chemical composition and association, the Greenhills dikes under discussion are here referred to as high-Mg arc-ankaramites, even where quenched, almost phenocryst-free, and consisting of almost monomineralic hornblende.

Arc-ankaramites of early Permian age, both effusive and intrusive, occur extensively in the Brook Street Terrane (Landis \& Waterhouse 1966, Williams \& Smith 1979, Sivell \& Rankin 1983, Ballard 1987). A possible link between these and intrusions such as the Greenhills 
Complex (Kimbrough et al. 1992) is discussed in this paper, but our focus is on the mineralogy and geochemistry of the Greenhills arc-ankaramite dikes.

\section{Analytical Methods}

Analyses of minerals were carried out at different stages of this study, initially with a JEOL JXA-5A electron microprobe using both wavelength-dispersion (WDS) and energy-dispersion (EDS) modes, and later using a JXA 8600 instrument (WDS). Operating conditions included beam diameter $2-3 \mu \mathrm{m}, 15 \mathrm{kV}$, and 20 $\mathrm{nA}$, and Bence \& Albee (1968) correction on drift, dead time, and background, or ZAF correction for more recent analyses. The EDS mode gave substantially higher detection-limits than WDS, e.g., about $0.2 \%$ for $\mathrm{TiO}_{2}$, $0.2 \%$ for $\mathrm{MnO}, 0.4 \%$ for $\mathrm{MgO}, 0.3 \%$ for $\mathrm{NiO}, 0.13 \%$ for $\mathrm{CaO}, 0.4 \%$ for $\mathrm{Na}_{2} \mathrm{O}, 0.1 \%$ for $\mathrm{K}_{2} \mathrm{O}$, and $0.2 \%$ for $\mathrm{Cr}_{2} \mathrm{O}_{3}$ in typical analyses of olivine, pyroxene, and amphibole. Details of the computer-controlled procedure for the JEOL JXA-5A are given in Kawachi \& Okumura (1978).

For whole rocks, the concentrations of the major elements were determined on fused discs by X-ray fluorescence (XRF) with a Philips PW 2400 spectrometer fitted with a rhodium tube. The flux used was a lithium carbonate - lithium oxide mix (type 1222). Concentrations of trace elements also were determined on the PW2400 using pressed powder discs. Corrections for line overlap and various mass-absorption effects were based on Philips SuperQ software modified with some in-house procedures to improve accuracy and precision. For rare-earth $(R E E)$ and certain other elements, inductively coupled plasma - mass spectrometry (ICP-MS) analyses were performed at Memorial University of Newfoundland by Simon E. Jackson. Some analyses for the $R E E$ were carried out by instrumental neutron-activation analyses (INAA) by Roy Johnstone at the Department of Geology, University of Otago. The INAA analyses, following the techniques described by Gibson \& Jagam (1980), gave results within analytical error of the ICP values.

\section{Field Relations}

Over a dozen late ankaramitic dikes are known at Greenhills. The best exposed are at the margins of the complex at Steep Head in the northwest, and in the southeast contact-zone about $3 \mathrm{~km}$ east of Barracouta Point (Fig. 1). They are postdated by only a few minor aplite dikes (Mossman 1973). Unlike many earlier dikes, they have undergone no noticeable solid-state deformation. They range in thickness from only about $4 \mathrm{~cm}$ to 1 $\mathrm{m}$. All were emplaced in country rock, mostly wehrlite, that had cooled sufficiently to undergo brittle fracture. The Steep Head hornblende ankaramite dike (Fig. 2) strikes $150^{\circ}$, dips $70^{\circ} \mathrm{NE}$, cross-cuts coarse-grained feldspathic wehrlite and earlier dikes and veinlets of medium-grained gabbronorite, and is exposed along $30 \mathrm{~m}$ of strike. This dike has phenocryst-free chilled margins consisting mostly of fine-grained amphibole, which grade over a centimeter or less into a phenocrystrich core. Most of the other dikes studied contain plagioclase, clinopyroxene, orthopyroxene, and hornblende, together with olivine and spinel-group minerals. Fineand medium-grained dikes of less extreme basaltic to andesitic composition, rich in groundmass hornblende, are locally abundant, especially in the marginal zones of the intrusion. Cross-cutting relations between these and the relatively few high-Mg dikes have not been observed.

\section{Petrography}

\section{Country-rock wehrlite (OU 25853W, 30999W)}

The immediate country-rock wehrlite for dike specimen OU 30999 (OU numbers refer to specimens stored in the Department of Geology, University of Otago, New Zealand) in the southeastern contact-zone consists of an aggregate of diopside averaging $\mathrm{Ca}_{48.4} \mathrm{Mg}_{47.2} \mathrm{Fe}_{4.4}$

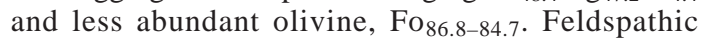
wehrlite OU 25853W at Steep Head is more evolved; diopside, crystals of which locally reach $2 \mathrm{~cm}$ in diameter, has an average core composition $\mathrm{Ca}_{46.1} \mathrm{Mg}_{46.7} \mathrm{Fe}_{7.2}$, and $\mathrm{Ca}_{46.2} \mathrm{Mg}_{45.4} \mathrm{Fe}_{8.4}$ at the rims. Olivine, $\mathrm{Fo}_{75.2-73.6}$, is less abundant and is commonly included within diopside crystals, and minor anorthite occurs interstitially. In both types of wehrlite, the diopside is heavily charged with blebs of amphibole of late magmatic origin.

\section{Steep Head hornblende ankaramite dike (OU 25853, 25857, 54983)}

Parts of the margin of a hornblende ankaramite dike, $30 \mathrm{~cm}$ thick, at grid reference E47 434991 on the north side of Steep Head (Table 1, Fig. 2), consist of a monomineralic veneer, $0.5-1.0 \mathrm{~mm}$ thick, of hornblende crystals, pale green in thin section, typically $0.05-0.1$ $\mathrm{mm}$ long, crudely oriented parallel to the dike margin (Fig. 3A). Elsewhere, a few percent of interstitial plagioclase, or products of its alteration, extend to the contact. Modal analysis of the marginal zone shows $91.3 \%$ hornblende, $8.5 \%$ plagioclase, $0.2 \%$ opaque grains and a trace of clinochlore. At $3 \mathrm{~mm}$ from the contact, hornblende crystals have increased to $0.15 \mathrm{~mm}$ in length, and interstitial plagioclase is present; at $6 \mathrm{~mm}$ from the contact, the grain size is $0.2-0.3 \mathrm{~mm}$; at $15 \mathrm{~mm}$ from the contact, hornblende occurs as plates up to $0.5 \mathrm{~mm}$ in diameter. From here to the center, there is no plagioclase, and the groundmass is virtually monomineralic hornblende in random orientation.

Phenocrysts of olivine and subordinate diopside first appear about $4 \mathrm{~cm}$ from the contact, and increase progressively in abundance to about $36 \%$ olivine and $10 \%$ diopside in the central portion of the dike. The whole- 
TABLE 1. HIGH-Mg ANKARAMITIC DIKES AND THEIR MINERALOGY, GREENHILLS COMPLEX

\begin{tabular}{|c|c|c|c|c|c|c|}
\hline & OU $25853 / 7$ & OU 44991 & OU 30999 & OU 44996 & OU 54982 & OU 54981 \\
\hline Locality & Steep Head & SE C.Z. & SE C.Z. & SE C.Z. & Steep Head & Steep Head \\
\hline Dike thickness & $30 \mathrm{~cm}$ & $? 30 \mathrm{~cm}$ & $15 \mathrm{~cm}$ & $70 \mathrm{~cm}$ & $15 \mathrm{~cm}$ & $8 \mathrm{~cm}$ \\
\hline $\mathrm{MgO}$ wt. $\%$, dike margin & $17.4 \%$ & & & & & $10.6 \%$ \\
\hline wt. $\%$ in dike interior & $28.3 \%$ & $26.0 \%$ & $24.2 \%$ & $17.0 \%$ & $16.4 \%$ & $14 \%$ \\
\hline$\%$ olivine phenocrysts & $10-36$ & 32 & $120-25$ & 6 & 16 & $11-6$ \\
\hline$\%$ cpx phenocrysts & ${ }^{1} 0-10$ & 2 & $18-12$ & 25 & 24 & $14-3$ \\
\hline Olivine & [11] & [19] & [43] & [15] & [10] & {$[10]$} \\
\hline $\mathrm{Mg} \#$ range & $92.7-81.7$ & $85.9-80.5$ & $90.0-76.1$ & $79.9-74.2$ & $74.1-72.4$ & $74.9-72.8$ \\
\hline Clinopyroxene & & & & & & \\
\hline phenocrysts avg. & {$[7$} & {$[8]$} & {$[11]$} & {$[14]$} & {$[10]$} & - \\
\hline $\mathrm{Ca}$ & 50.1 & 48.2 & 46.7 & 46.8 & 45.5 & - \\
\hline $\mathrm{Mg}$ & 40.3 & 46.4 & 46.1 & 45.1 & 45.1 & - \\
\hline $\mathrm{Fe}$ & 9.6 & 5.4 & 7.3 & 8.0 & 9.3 & - \\
\hline groundmass avg. & absent & {$[9]$} & {$[6]$} & {$[10]$} & {$[12]$} & {$[17]$} \\
\hline $\mathrm{Ca}$ & - & 47.7 & 46.4 & 46.1 & 44.0 & 45.3 \\
\hline $\mathrm{Mg}$ & - & 47.9 & 45.9 & 44.3 & 44.8 & 44.9 \\
\hline $\mathrm{Fe}$ & - & 4.4 & 7.7 & 9.6 & 11.3 & 9.8 \\
\hline \multicolumn{7}{|l|}{ Orthopyroxene } \\
\hline groundmass avg. & absent & {$[9]$} & [12] & [10] & [15] & [13] \\
\hline $\mathrm{Ca}$ & - & 1.2 & 1.4 & 2.1 & 2.2 & 2.5 \\
\hline $\mathrm{Mg}$ & - & 84.6 & 80.3 & 72.1 & 73.0 & 73.9 \\
\hline $\mathrm{Fe}$ & - & 14.3 & 18.3 & 25.8 & 24.8 & 23.6 \\
\hline $\mathrm{Mg} \#$ range & - & $87.9-84.5$ & $82.9-79.6$ & $76.4-69.9$ & $78.5-73.2$ & $77.6-73.5$ \\
\hline \multicolumn{7}{|l|}{ Chromite, magnetite } \\
\hline in olivine & [6] & [6] & {$[40]$} & [5] & {$[2$, in $c p x]$} & - \\
\hline range $\mathrm{Cr}_{2} \mathrm{O}_{3}$ & $53.4-48.4$ & $41.5-33.5$ & $53.1-12.1$ & $25.6-8.7$ & $24.5,20.3$ & - \\
\hline in groundmass & - & [9] & [9] & {$[8]$} & {$[10]$} & [11] \\
\hline range $\mathrm{Cr}_{2} \mathrm{O}_{3}$ & - & $38.6-30.1$ & $9.44-0.26$ & $12.7-0.79$ & $8.00-3.75$ & $5.81-2.91$ \\
\hline Plagioclase & [9] & [14] & {$[10]$} & {$[17]$} & [12] & {$[20]$} \\
\hline An range & Ang9.3-94.0 & An95.3-80.8 & An $88.6-75.3$ & Ang $94.7-72.0$ & Ang0.0-82.7 & An90.0-78.8 \\
\hline \multicolumn{7}{|l|}{ Amphibole } \\
\hline $\begin{array}{l}\text { avg. magmatic brown } \\
\text { and } 25853 \text { "quench" }\end{array}$ & [5] & [16] & [6] & [11] & [12] & [10] \\
\hline $\mathrm{Ca}$ & 28.7 & 31.2 & 29.2 & 29.6 & 29.0 & 29.6 \\
\hline $\mathrm{Mg}$ & 55.0 & 59.0 & 55.8 & 52.3 & 51.4 & 50.9 \\
\hline $\mathrm{Fe}$ & 16.3 & 9.8 & 15.0 & 18.0 & 19.6 & 19.5 \\
\hline $\mathrm{Al}_{2} \mathrm{O}_{3}$, wt $\%$ & 6.3 & 11.5 & 10.8 & 10.5 & 11.3 & 11.6 \\
\hline green, avg. & {$[10]$} & & [2] & {$[7]$} & trace & present \\
\hline Ca & 28.2 & - & 29.5 & 28.2 & - & - \\
\hline $\mathrm{Mg}$ & 56.8 & - & 62.0 & 55.3 & - & - \\
\hline $\mathrm{Fe}$ & 14.9 & - & 8.6 & 16.5 & - & - \\
\hline $\mathrm{Al}_{2} \mathrm{O}_{3}, \mathrm{wt} \%$ & 9.01 & - & 11.1 & 8.8 & - & - \\
\hline blebs in cpx, avg. & {$[5]$} & {$[9]$} & {$[7]$} & {$[9]$} & {$[8]$} & {$[7]$} \\
\hline $\mathrm{Ca}$ & 29.4 & 29.6 & 30.4 & 29.9 & 29.7 & 28.5 \\
\hline $\mathrm{Mg}$ & 59.4 & 55.0 & 57.5 & 53.3 & 54.2 & 52.9 \\
\hline $\mathrm{Fe}$ & 11.3 & 15.4 & 12.1 & 16.7 & 16.1 & 18.7 \\
\hline $\mathrm{Al}_{2} \mathrm{O}_{3}, \mathrm{wt} \%$ & 8.1 & 10.3 & 8.5 & 9.5 & 8.5 & 9.1 \\
\hline late stage, avg. & & & {$[1]$} & {$[5]$} & & present \\
\hline $\mathrm{Ca}$ & - & - & 27.1 & 26.7 & - & $r-$ \\
\hline $\mathrm{Mg}$ & - & - & 57.0 & 64.0 & - & - \\
\hline $\mathrm{Fe}^{\circ}$ & - & - & 15.9 & 9.4 & - & - \\
\hline $\mathrm{Al}_{2} \mathrm{O}_{3}$, wt $\%$ & - & - & 5.7 & 3.3 & - & - \\
\hline
\end{tabular}

SE C.Z. Southeast Contact Zone. MgO wt.\% on anhydrous basis.

1 Range from rim of dike (about $1 \mathrm{~cm}$ thick) to interior.

$[n]$ Number of electron microprobe analyses made. $\mathrm{Mg} \#=100 \mathrm{Mg} /(\mathrm{Mg}+\mathrm{Fe})$.

$\mathrm{Ca}, \mathrm{Mg}, \mathrm{Fe}$ in atomic proportions. 


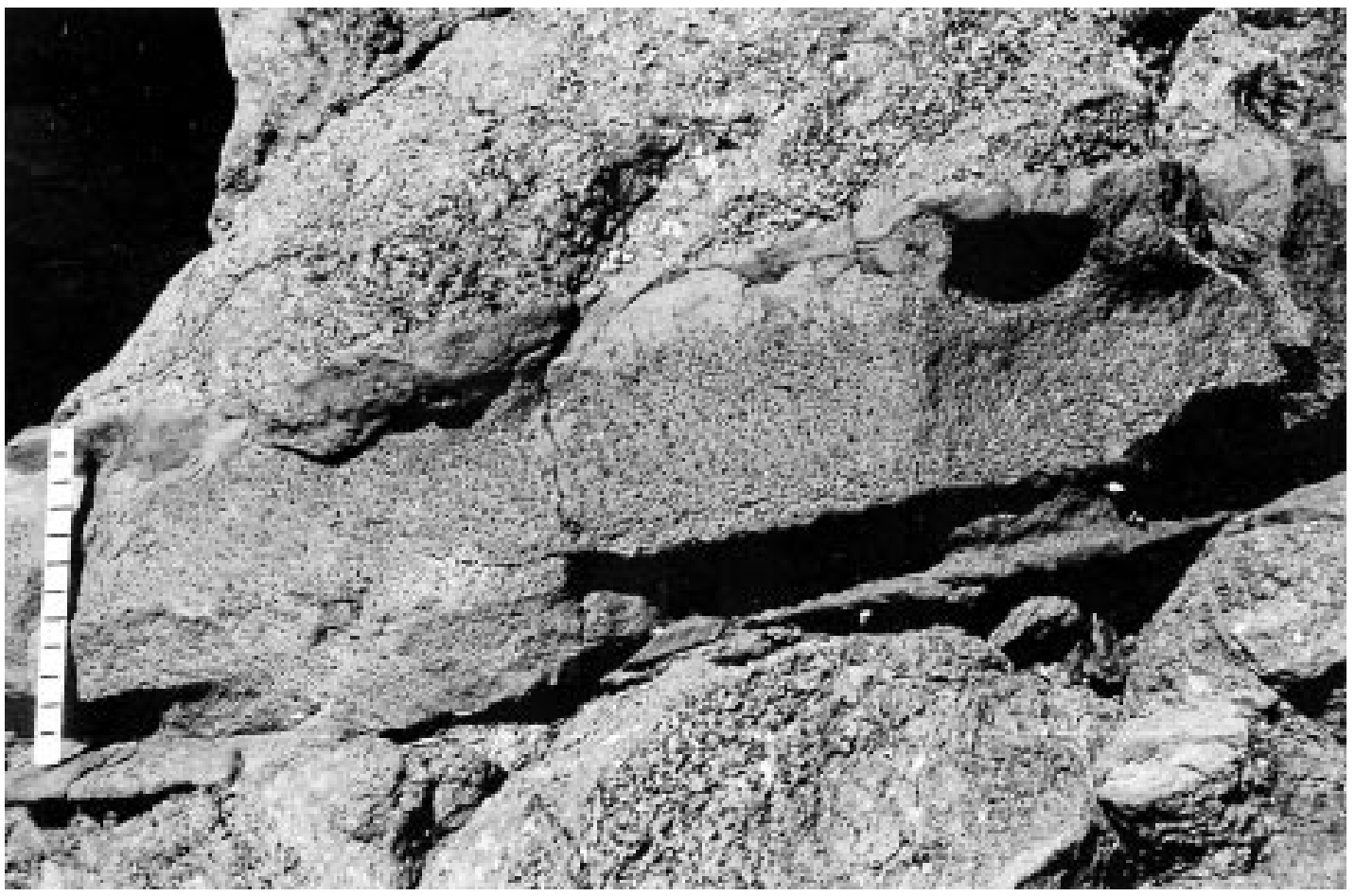

FIG. 2. Hornblende-rich high-Mg ankaramitic dike (OU 25853, 25857, 54983) of the Greenhills Complex intruded into wehrlite at Steep Head. Pitted surface is due to weathering of olivine phenocrysts. Note chilled, phenocryst-poor margins. The rule is $30 \mathrm{~cm}$ in length.

rock $\mathrm{Mg}$ content increases correspondingly from 17.4 $\mathrm{wt} \% \mathrm{MgO}$ on an anhydrous basis near the margin to $28.3 \%$ in the interior. The olivine crystals tend to be euhedral, but a few are conspicuously skeletal (Fig. 4). Variation in grain size and amount of phenocrysts (Fig. 5) are similar to those in Hebridean picrite dikes illustrated by Drever \& Johnston (1958). As in all the dikes here described, diopside crystals are liberally studded with oriented inclusions of pale brownish green to greenish brown hornblende. Hornblende more extensively replaces the margins and interiors of some diopside crystals, a few of which are replaced by single hornblende crystals with inclusions of clinochlore. Spinel octahedra, typically about $50 \mu \mathrm{m}$ in diameter, are abundant. They occur as inclusions in olivine, as granules within embayments in olivine, and as euhedral phenocrysts in the central portion of this and some of the other dikes.

In an experimental study of olivine morphology, Donaldson (1976) showed that a systematic change in shape of olivine crystals from polyhedral or granular through amoeboid (hopper) to platy or feathery correlated with increasing cooling rate and degree of supercooling. He also observed that the larger the normative olivine content of a melt, the slower the cooling rate at which a given olivine morphology will develop. Thus the amoeboid shapes of some of the olivine crystals, together with the high normative olivine content of the dikes, are compatible with slower cooling and a lower degree of supercooling than would lead to similar textures in a less magnesian liquid.

As with other dikes here described, this dike contains some clearly secondary minerals. Minor alteration of plagioclase has given rise to products including montmorillonite, fine-grained white mica, zeolites, and prehnite. Tiny pools of polysynthetically twinned $\mathrm{Mg}$ rich chlorite, possibly formed from glass, are common at the head of embayments in olivine. Olivine crystals in the interior of the dike, as in some of the other high$\mathrm{Mg}$ dikes, are outlined in black by curving or dog-tooth lines of opaque inclusions (Fig. 3B). There is some veining of olivine by serpentine, and marginal replacement by serpentine and secondary fibrous amphibole. Finegrained patches with inwardly radiating aggregates of amphibole are interpreted as late-stage pseudomorphs after pyroxene.

The near-monomineralic hornblende matrix of this rock might be interpreted (1) as a product of direct quenching of a hydrous melt (Yoder \& Tilley 1962), (2) as a replacement of glass, or (3) as a late-stage replace- 

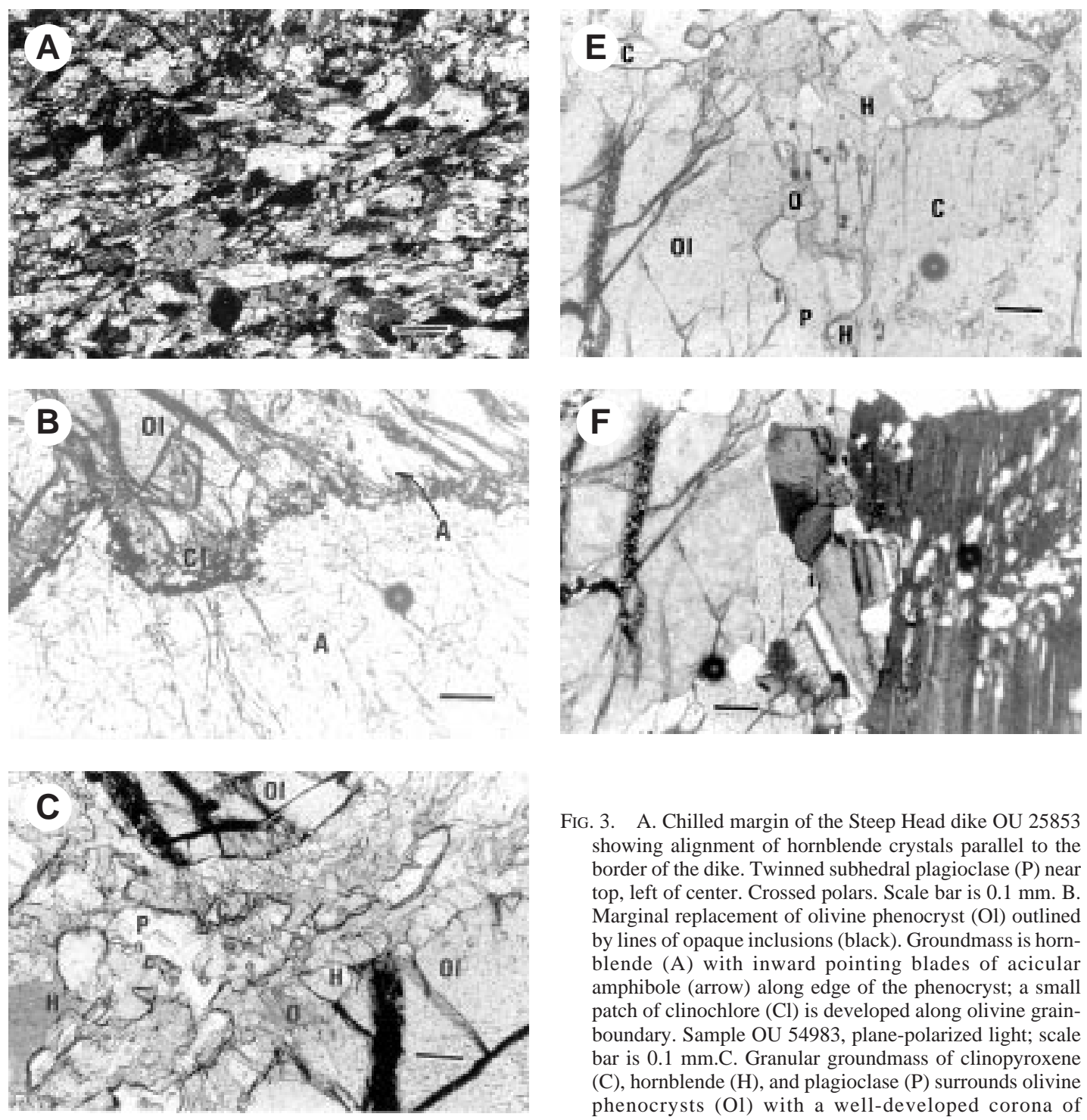

FIG. 3. A. Chilled margin of the Steep Head dike OU 25853 showing alignment of hornblende crystals parallel to the border of the dike. Twinned subhedral plagioclase $(\mathrm{P})$ near top, left of center. Crossed polars. Scale bar is $0.1 \mathrm{~mm}$. B. Marginal replacement of olivine phenocryst $(\mathrm{Ol})$ outlined by lines of opaque inclusions (black). Groundmass is hornblende (A) with inward pointing blades of acicular amphibole (arrow) along edge of the phenocryst; a small patch of clinochlore $(\mathrm{Cl})$ is developed along olivine grainboundary. Sample OU 54983, plane-polarized light; scale bar is $0.1 \mathrm{~mm}$.C. Granular groundmass of clinopyroxene (C), hornblende $(\mathrm{H})$, and plagioclase $(\mathrm{P})$ surrounds olivine phenocrysts $(\mathrm{Ol})$ with a well-developed corona of orthopyroxene (O) and hornblende (H). Sample OU 30999, plane-polarized light; scale bar is $0.1 \mathrm{~mm}$. D. Brown hornblende $(\mathrm{H})$ is moulded on olivine $(\mathrm{Ol})$, orthopyroxene $(\mathrm{O})$, clinopyroxene $(\mathrm{C})$ and plagioclase $(\mathrm{P})$; magnetite grains (black) coprecipitated with hornblende. Sample OU 54981, plane polarized light; scale bar is $0.1 \mathrm{~mm}$. E. Phenocryst of olivine (Ol) and clinopyroxene (C) set in granular groundmass of olivine (not present in this view), clinopyroxene $(\mathrm{C})$, orthopyroxene $(\mathrm{O})$, and plagioclase $(\mathrm{P})$. Late magmatic hornblende $(\mathrm{H})$ occurring as an oikocryst in the groundmass is in optical continuity with blebs throughout the clinopyroxene phenocryst. Sample OU 54982, planepolarized light; scale bar is $0.1 \mathrm{~mm}$. F. Essentially same field of view as Figure 3E, with crossed polars. Elongate lamellae of orthopyroxene are visible in clinopyroxene crystal at right. Sample OU 54982; scale bar is $0.1 \mathrm{~mm}$ ). 


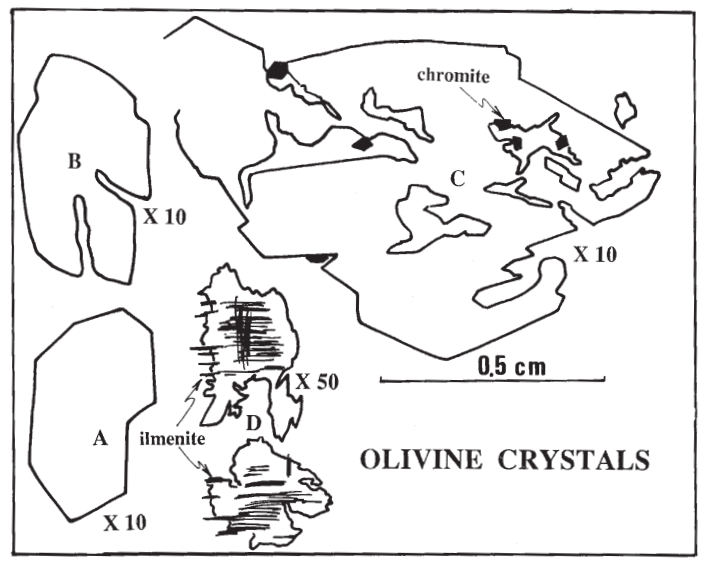

FIG. 4. Outlines of olivine crystals from high-Mg ankaramitic dikes, Greenhills Complex: A, B, and C from Steep Head dike (OU 25857) reveal a gradation from euhedral crystals to hopper-like skeletal forms (Drever \& Johnston 1957). Olivine D from the chilled margin of a dike (OU 25868) contains rods of ilmenite as a result of postmagmatic replacement.

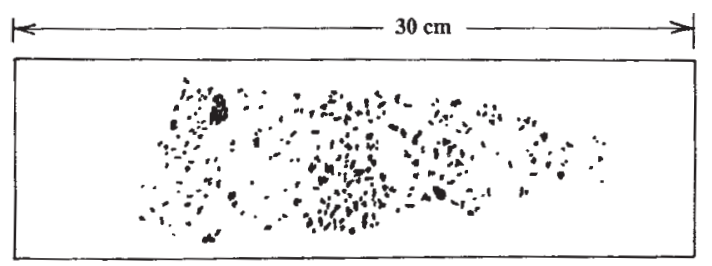

FIG. 5. Sketch showing variation in size and amount of phenocrysts (mainly olivine) across the Steep Head hornblende-rich ankaramite dike. Compare Drever \& Johnston (1958, p. 479).

ment either of glass or of a fine-grained pyroxene-bearing mineral aggregate such as occurs in the quench zones of the other dikes. Recognizable grain-shapes of other minerals are not preserved, however, nor are feathery quench-textures. The interpretation remains equivocal.

\section{Hornblende ankaramite dike $0.8 \mathrm{~km}$ south of Steep Head (OU 25826)}

This dike contains phenocrysts of clinopyroxene (18\%) exceeding in abundance those of olivine (7\%). It also contains sparse phenocrysts of plagioclase and chromian spinel. Clinopyroxene phenocrysts are replaced along their margins and thinly overgrown by pale green hornblende, and olivine by a corona of orthopyroxene. The matrix consists of subequal amounts of brownish green hornblende (some probably primary, some as a replacement of clinopyroxene) and laths of plagioclase, $0.1-0.2 \mathrm{~mm}$ long. Grain size does not increase perceptibly inward from the contact.

\section{Dikes in the southeast contact-zone,} about $3 \mathrm{~km}$ east of Barracouta Point (OU 30999, 44991, 44992, 44996)

Hornblende ankaramite dike OU 44991 (26.0\% $\mathrm{MgO}$ on a volatile-free basis), about $30 \mathrm{~cm}$ thick, contains 32\% euhedral phenocrysts of olivine (Fo85.9-80.5) and about $2 \%$ phenocrysts of diopside, both up to $6 \mathrm{~mm}$ in diameter, set in a granular groundmass of clinopyroxene, orthopyroxene, abundant pale brownish hornblende, and subordinate plagioclase. Near the edge of the dike, groundmass pyroxene and plagioclase range in diameter from 0.05 to $0.2 \mathrm{~mm}$. Hornblende oikocrysts reach $0.2 \mathrm{~mm}$. In the dike center, the average grain-size is $0.3 \mathrm{~mm}$, except for hornblende crystals, many of which exceed $1 \mathrm{~mm}$. As in most of the dikes, chromian spinel is enclosed in olivine phenocrysts and in the groundmass.

Dike OU 30999, $15 \mathrm{~cm}$ thick, contains $24.2 \% \mathrm{MgO}$ on an anhydrous basis. Modal analyses indicate a barely significant increase in phenocrysts of olivine and clinopyroxene up to $6 \mathrm{~mm}$ in diameter, from about $20 \%$ and $8 \%$, respectively, within two centimeters of the contact to about $25 \%$ and $12 \%$ in the dike interior. The olivine has a corona of orthopyroxene (Fig. 3C), and ranges in composition from $\mathrm{Fo}_{90.0}$ to $\mathrm{Fo}_{76.1}$. The groundmass is granular to micropoikilitic, with variable grain-size, 0.1$1 \mathrm{~mm}$. Hornblende is the most abundant constituent, moulded on or enclosing euhedral grains of plagioclase, clinopyroxene, orthopyroxene, and minor opaque minerals.

Dike OU 44992 (not analyzed) approaches the hornblende ankaramite end-member, with copious phenocrysts of olivine and very little feldspar, but apart from oikocrysts of hornblende and some granules of clinopyroxene and relict plagioclase, the groundmass is thoroughly reconstituted to finely felted secondary amphibole, chlorite and other products of alteration.

A dike $70 \mathrm{~cm}$ thick with $17.0 \% \mathrm{MgO}$, OU 44996, contains $25 \%$ phenocrysts of clinopyroxene, about 5 $\mathrm{mm}$ in diameter. These are studded with blebs and larger inclusions of hornblende, which are pale brown in the interior of the host crystals and greenish nearer the edges. Here, they are in optical continuity with similarly oriented crystals of hornblende in the groundmass, which in turn are zoned from brownish centers to greenish margins. Olivine phenocrysts $\left(\mathrm{Fo}_{79.9-74.2}\right)$ are less abundant $(\sim 6 \%)$ and are mantled with orthopyroxene. The groundmass consists of orthopyroxene, clinopyroxene, and plagioclase about $0.2-1 \mathrm{~mm}$ across, together with opaque spinel, abundant 1-2-mm plates of hornblende, secondary actinolitic amphibole, and other minor products of alteration. 
Ankaramitic hornblende microgabbronorite dikes at Steep Head (OU 54981, 54982)

Two dikes about $200 \mathrm{~m}$ south of the Steep Head hornblende ankaramite dike, at grid reference E47 434989, are less Mg-rich, less rich in hornblende, and less finely chilled than the other dikes here described. Ankaramitic hornblende microgabbronorite dike OU $54982,15 \mathrm{~cm}$ thick, contains abundant phenocrysts of clinopyroxene and olivine up to $8 \mathrm{~mm}$ in diameter. Phenocrysts are more abundant in the interior of the dike (clinopyroxene $24 \%$, olivine $16 \%$ ), in which the groundmass is coarser grained $(0.1-0.6 \mathrm{~mm})$ than at the contact $(0.05-0.3 \mathrm{~mm})$. Olivine $\left(\mathrm{Fo}_{74.1-72.4}\right)$ is deeply corroded. The groundmass contains much orthopyroxene as well as clinopyroxene, plagioclase, brown hornblende (which occurs as small oikocrysts and locally replaces the margins of clinopyroxene phenocrysts) and granules of titaniferous magnetite, $10-50 \mu \mathrm{m}$ in diameter (Fig. 3D). Some grains of hornblende contain dactylic titaniferous magnetite. Blebs of pale Mg-rich amphibole are well developed in the clinopyroxene phenocrysts (Figs. 3E, F).

The marginal zone of a nearby dike (OU 54981), $8 \mathrm{~cm}$ thick, is an aggregate of orthopyroxene, clinopyroxene, and plagioclase grains about $0.1-0.3 \mathrm{~mm}$ in diameter, together with finer-grained granules of magnetite and a late-stage rim of hornblende. It contains small flow-aligned phenocrysts of clinopyroxene (4\%) and rarer olivine and plagioclase. The matrix in the center of the dike has a grain size of about $0.3 \mathrm{~mm}$. It contains deeply corroded phenocrysts of olivine $(6 \%$,
Fo74.9-72.8) rimmed with orthopyroxene, and less abundant phenocrysts of clinopyroxene $(3 \%)$, plates of plagioclase to $1 \mathrm{~mm}$, and scattered oikocrysts of latemagmatic brown hornblende moulded on the other minerals. As in other rocks here described, oriented blebs of hornblende in clinopyroxene are in the same optical orientation as hornblende overgrowths on the same crystals.

In OU 54981, the concentration of Mg increases on a volatile-free basis from $10.6 \% \mathrm{MgO}$ at the margin to $14.0 \% \mathrm{MgO}$ in the more olivine-rich interior; OU 54982 contains $16.4 \% \mathrm{MgO}$ in the central part. Both rocks are little altered, and show little replacement of primary magmatic minerals by amphibole.

\section{MinerALOGY}

\section{Forsterite}

Observed compositions (Tables 1,2) of olivine in the Steep Head hornblende ankaramite dike OU 25853, 25857 range from $\mathrm{Fo}_{92.7}$ to $\mathrm{Fo}_{81.7}$, with zoning of up to $9 \%$ from core to rim in individual crystals. These compositions are much more magnesian than those of forsterite in the feldspathic wehrlite country-rock, Fo75.2-73.6. Compositions of olivine in the southeastern contact zone dike OU 30999, Fo90.0-76.1, average Fo ${ }_{82}$, also contrast with those, $\mathrm{Fo}_{86.8-84.7}$, in its country-rock, a feldspar-free wehrlite. Relative abundances of olivine and clinopyroxene in both cases are reversed in the dikes as compared with the country rocks. These facts indicate that the majority of phenocrysts are not xenocrysts

TABLE 2. REPRESENTATIVE EMPA DATA FOR OLIVINE-CHROMITE AND OLIVINE-CIIROMIAN MAGNETITE PAIRS IN HIGH-Mg ANKARAMITIC DIKES, GREENI IILLS COMPLIXX

\begin{tabular}{|c|c|c|c|c|c|c|c|c|c|c|c|c|c|c|}
\hline OU no. & \multicolumn{2}{|c|}{25857} & \multicolumn{2}{|c|}{ 30999A } & \multicolumn{2}{|c|}{$30999 \mathrm{~A}$} & \multicolumn{2}{|c|}{$30999 \mathrm{~B}$} & \multicolumn{2}{|c|}{44996} & \multicolumn{2}{|c|}{30999} & \multicolumn{2}{|c|}{44996} \\
\hline & *ol & ${ }^{*} \mathrm{Cr}$ & ol & Cr & ol & $\mathrm{cr}$ & ol & $\mathrm{cr}$ & ${ }^{*} \mathrm{ol}$ & ${ }^{*} \mathrm{cr} \mathrm{mt}$ & ${ }^{*} \mathrm{Ol}$ & ${ }^{*} \mathrm{cr} \mathrm{ml}$ & ${ }^{*} \mathrm{ol}$ & ${ }^{x} \mathrm{cr} \mathrm{mt}$ \\
\hline $\mathrm{SiO}_{2}$ & 41.52 & 0.03 & 40.85 & 1.15 & 40.25 & 1.33 & 39.98 & 1.18 & 40.27 & & & 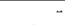 & 39.57 & \\
\hline $\mathrm{TiO}_{2}$ & 0.01 & 0.26 & b.d. & b.d. & b.d. & 1.02 & b.d. & 0.60 & b.d. & 0.42 & - & 1.16 & b.d. & 0.11 \\
\hline $\mathrm{Al}_{2} \mathrm{O}_{3}$ & 0.07 & 10.80 & b.d. & 10.77 & b.d. & 11.91 & b.d. & 13.40 & b.d. & 3.52 & - & 4.27 & b.d. & 2.56 \\
\hline $\mathrm{Cr}_{2} \mathrm{O}_{3}$ & 0.15 & 51.54 & b.d. & 45.17 & b.d. & 31.19 & b.d. & 30.60 & b.d. & 25.62 & 0.02 & 14.1 & b.d. & 8.73 \\
\hline $\mathrm{V}_{2} \mathrm{O}_{3}$ & - & - & - & 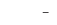 & - & - & - & $\cdots$ & - & 0.13 & - & - & - & 0.19 \\
\hline $\mathrm{Fe}_{2} \mathrm{O}_{3}$ & - & 6.42 & - & 9.11 & - & 19.37 & - & 19.48 & - & 37.19 & - & 45.56 & - & 56.24 \\
\hline $\mathrm{FeO}$ & 7.68 & 23.05 & 13.82 & 29.22 & 17.34 & 32.13 & 18.17 & 30.77 & 20.03 & 29.66 & 21.8 & 30.20 & 22.07 & 30.08 \\
\hline $\mathrm{MnO}$ & 0.09 & 0.27 & b.d. & 0.50 & b.d. & 0.79 & b.d. & 0.50 & 0.34 & 0.42 & - & 0.33 & 0.19 & 0.17 \\
\hline $\mathrm{MgO}$ & 50.54 & 6.73 & 43.73 & 3.31 & 41.47 & 2.21 & 41.30 & 2.97 & 39.57 & 1.06 & 39.5 & 0.97 & 37.02 & 0.61 \\
\hline $\mathrm{CaO}$ & 0.26 & 0.06 & b.d. & 0.13 & b.d. & b.d. & b.d. & b.d. & b.d. & b.d. & - & - & b.d. & b.d. \\
\hline $\mathrm{NiO}$ & 0.26 & 0.08 & b.d. & b.d. & b.d. & b.d. & b.d. & b.d. & 0.34 & 0.19 & - & - & 0.13 & 0.20 \\
\hline Total & 100.58 & 99.24 & 98.40 & 99.36 & 99.06 & 99.95 & 99.45 & 99.50 & 100.55 & 98.21 & - & 96.59 & 98.98 & 98.89 \\
\hline
\end{tabular}

\begin{tabular}{|c|c|c|c|c|c|c|c|c|c|c|c|c|c|c|}
\hline $\mathrm{Si}$ & 1.002 & 0.01 & 1.031 & 0.32 & 1.027 & 0.37 & 1.020 & 0.33 & 1.027 & - & - & & 1.034 & \\
\hline $\mathrm{Ti}$ & 0.000 & 0.05 & - & - & - & 0.21 & - & 0.12 & - & 0.10 & - & 0.27 & - & 0.03 \\
\hline Al & 0.002 & 3.47 & - & 3.53 & - & 3.91 & - & 4.36 & - & 1.25 & - & 1.54 & - & 0.92 \\
\hline $\mathrm{Cr}$ & 0.003 & 11.10 & - & 9.92 & - & 6.87 & - & 6.68 & - & 6.10 & - & 3.41 & - & 2.10 \\
\hline V & - & - & - & - & - & - & - & - & - & 0.03 & - & - & - & 0.05 \\
\hline $\mathrm{Fe}^{34}$ & . & 1.31 & - & 1.91 & - & 4.06 & - & 4.05 & - & 8.43 & - & 10.51 & - & 12.88 \\
\hline $\mathrm{Fe}^{2+}$ & 0.155 & 5.25 & 0.292 & 6.79 & 0.370 & 7.48 & 0.388 & 7.11 & 0.427 & 7.47 & - & 7.74 & 0.482 & 7.66 \\
\hline $\mathrm{Mn}$ & 0.002 & 0.06 & - & 0.12 & - & 0.19 & - & 0.12 & 0.007 & 0.11 & - & 0.09 & 0.004 & 0.04 \\
\hline $\mathrm{Mg}$ & 1.819 & 2.73 & 1.645 & 1.37 & 1.577 & 0.92 & 1.571 & 1.22 & 1.505 & 0.48 & - & 0.44 & 1.442 & 0.28 \\
\hline $\mathrm{Ca}$ & 0.007 & 0.02 & - & 0.04 & - & - & - & - & - & - & - & - & - & \\
\hline $\mathrm{Ni}$ & 0.005 & 0.01 & - & - & - & - & $\therefore$ & - & 0.0007 & 0.05 & - & - & 0.003 & 0.05 \\
\hline Total & 2.995 & 24.00 & 2.968 & 24.00 & 2.974 & 24.00 & 2.979 & 24.00 & 2.973 & 24.00 & - & 24.00 & 2.965 & 2400 \\
\hline $\mathrm{Mg} \#$ & 92.1 & 34.2 & 84.9 & 16.8 & 81.0 & 10.7 & 80.4 & 14.6 & 77.9 & 6.0 & 76.4 & 4.8 & 74.9 & 3.5 \\
\hline
\end{tabular}

$30999 \mathrm{~A}$, dike edge; $30999 \mathrm{~B}$ and 30999 , dike interior. ${ }^{*}$ Analysis by WDS mode, others by $\mathrm{FDS}$.

lieO, $\mathrm{Fe}_{2} \mathrm{O}_{3}, \mathrm{Fe}^{2+}$, and $\mathrm{Fe}^{3+}$ are calculated to conform with chromite (cr) and chromian magnetite stoichiometry.

b.d.: below delection limits. - : not analysed for, and, for atomic proportions table, below detection limits. 
detached from the immediate country-rocks. Furthermore, the olivine crystals in the various dikes characteristically contain numerous small inclusions of chromite. Such inclusions are noticeably more sparse in the Greenhills dunites and wehrlites, although the dunites contain larger grains of chromite, averaging about $0.5 \mathrm{~mm}$ in diameter (Mossman 1973). It appears that under conditions of slow cooling in the main magma chamber, growing crystals of chromite tended not to be trapped in olivine. We conclude that the phenocrysts in the high-Mg dikes are in general not xenocrystic from the layered series. Their overall range of composition is from $\mathrm{FO}_{92}$ in some crystals in the Steep Head hornblende ankaramite dike to $\mathrm{Fo}_{72}$ in the ankaramitic hornblende microgabbronorite dikes near Steep Head. The range in composition in the more Mg-rich dikes suggests a lack of equilibration between crystals and what must have been rapidly evolving melts during emplacement of the dikes.

Calcium contents of $0.22-0.46$ wt $\% \mathrm{CaO}$, average $0.34 \%$, were determined in WDS analyses of olivine cores, Fo91.0-92.7, in the Steep Head hornblende ankaramite OU 25857. These levels imply a significantly higher temperature of crystallization than that of the rims, $\mathrm{Fo}_{81.7}$, average $0.10 \% \mathrm{CaO}$, of three olivine phenocrysts in the same rock (Jurewicz \& Watson 1988). In OU 30999, $\mathrm{CaO}$ contents of 0.02 to $0.05 \%$ in olivine $\mathrm{Fo}_{82-85}$ are near WDS detection limits, but also imply lower temperatures. Determinations of Ca concentration in olivine Fo79.9-72.4 in the less Mg-rich dikes are below the EDS detection limit of $0.12 \%$.

\section{Clinopyroxene and hornblende inclusions}

Clinopyroxene in feldspathic wehrlite country-rock at Steep Head is diopside which is distinctly richer in $\mathrm{Fe}$ and poorer in $\mathrm{Ca}$ than that in feldspar-free wehrlite at the southeastern contact-zone (Table 3, Fig. 6). As in all wehrlite of the Greenhills Complex, the diopside crystals are heavily charged with oriented blebs of hornblende typically $10-100 \mu \mathrm{m}$ long, ranging into larger replacements $0.5 \mathrm{~mm}$ long. Similar blebs are locally concentrated along cracks that presumably provided access for late magmatic or other fluids, but the majority are not visibly associated with such imperfections.

In the Steep Head hornblende ankaramite dike OU 25857, clinopyroxene occurs almost exclusively as diopside phenocrysts, approximately the same size as the olivine phenocrysts, although much less abundant. In the other analyzed dikes, clinopyroxene abounds in the groundmass and occurs also in varying abundance as phenocrysts. Most grains plot in the compositional field of diopside, with more than $45 \%$ of the $\mathrm{Ca}$ (Wo) component (Fig. 7). With increasing substitution of Fe for $\mathrm{Ca}$ and $\mathrm{Mg}$ in the more evolved rocks, they extend marginally into the field of augite. Compositions of clinopyroxene in the groundmass overlap with those of the phenocrysts. The Al, Na, and Ti contents in the clinopyroxene resemble those of arc suites such as in New Georgia (Ramsay et al. 1984), but are below those of typical lherzolite nodules and MORB. Chromium contents are variable, but typically are about $0.3 \%$ $\mathrm{Cr}_{2} \mathrm{O}_{3}$, as shown by WDS analyses (Table 3).

TABLE 3. REPRESENTATIVE EMPA DATA FOR CLINOPYROXENE IN WEHRLITE COUNTRY ROCK AND IN HIGH-Mg ANKARAMITIC DIKES, GREENHILLS COMPLEX

\begin{tabular}{|c|c|c|c|c|c|c|c|c|c|c|c|c|c|c|c|c|}
\hline \multirow[t]{2}{*}{ OU no. } & \multicolumn{2}{|c|}{$\begin{array}{c}\text { wehrlite } \\
\text { Steep Head } \\
25853 \mathrm{~W} \\
\end{array}$} & \multicolumn{2}{|c|}{$\begin{array}{c}\text { wehrlite } \\
\text { SE contact zone } \\
\text { 30999W }\end{array}$} & \multicolumn{2}{|c|}{$\begin{array}{c}\text { hbd ankaramite } \\
\text { Steep Head } \\
25857\end{array}$} & \multicolumn{2}{|c|}{$\begin{array}{c}\text { hbd ankaramite } \\
\text { SE contact zone } \\
44991\end{array}$} & \multicolumn{2}{|c|}{$\begin{array}{l}\text { hbd ankaramite } \\
\text { SE contact zone } \\
\text { 30999A }\end{array}$} & \multicolumn{2}{|c|}{$\begin{array}{c}\text { hbd ankaramite } \\
\text { SE contact zone } \\
44996\end{array}$} & \multicolumn{2}{|c|}{$\begin{array}{c}\text { hbd gabbronorite } \\
\text { Steep Head } \\
54982\end{array}$} & \multicolumn{2}{|c|}{$\begin{array}{c}\text { hbd gabbronorite } \\
\text { Steep Head } \\
54981\end{array}$} \\
\hline & core & rim & core & rim & ${ }^{*}$ core & *core & *core & ${ }^{*} \mathrm{rim}$ & ${ }^{*}$ core & ${ }^{*} \mathrm{rim}$ & ${ }^{*}$ core $^{2}$ & ${ }^{*}$ core $^{3}$ & core & $\mathrm{rim}$ & gndms & gndms \\
\hline $\mathrm{SiO}_{2}$ & 53.72 & 53.41 & 54.73 & 54.36 & 52.3 & 51.5 & 55.01 & 53.40 & 52.7 & 52.8 & 54.55 & 53.95 & 53.56 & 53.23 & 54.06 & 52.25 \\
\hline $\mathrm{Al}_{2} \mathrm{O}_{3}$ & 1.39 & 1.63 & 0.83 & 0.95 & 2.60 & 2.58 & 0.95 & 2.05 & 2.36 & 1.10 & 2.22 & 2.03 & 1.49 & 1.54 & 1.29 & 1.78 \\
\hline $\mathrm{TiO}_{2}$ & b.d. & b.d. & b.d. & b.d. & 0.33 & 0.23 & 0.05 & 0.15 & 0.13 & 0.12 & 0.23 & 0.25 & b.d. & 0.30 & b.d. & 0.22 \\
\hline $\mathrm{FeO}$ & 3.88 & 5.97 & 2.47 & 2.57 & 4.67 & 6.12 & 3.69 & 4.02 & 4.86 & 6.47 & 6.23 & 5.93 & 5.19 & 7.39 & 5.58 & 6.90 \\
\hline $\mathrm{MnO}$ & b.d. & b.d. & b.d. & b.d. & 0.37 & 0.36 & 0.13 & 0.13 & 0.09 & 0.19 & 0.06 & 0.20 & b.d. & 0.32 & b.d. & b.d. \\
\hline $\mathrm{MgO}$ & 17.45 & 16.10 & 17.27 & 16.93 & 14.5 & 13.7 & 16.88 & 16.56 & 16.7 & 15.7 & 16.46 & 15.02 & 15.82 & 15.32 & 16.13 & 15.26 \\
\hline $\mathrm{CaO}$ & 23.20 & 22.98 & 24.88 & 24.67 & 23.7 & 24.4 & 23.30 & 23.57 & 23.1 & 23.2 & 20.55 & 21.97 & 23.30 & 22.28 & 22.96 & 22.18 \\
\hline $\mathrm{Na}_{2} \mathrm{O}$ & 0.35 & 0.34 & 0.42 & 0.50 & 0.24 & 0.22 & 0.24 & 0.16 & 0.11 & 0.25 & 0.15 & 0.20 & b.d. & b.d. & b.d. & b.d. \\
\hline $\mathrm{Cr}_{2} \mathrm{O}_{3}$ & b.d. & b.d. & b.d. & b.d. & 0.43 & 0.55 & 0.21 & 0.95 & 0.31 & 0.04 & 0.24 & 0.33 & b.d. & 0.36 & b.d. & b.d. \\
\hline Total & 99.99 & 100.43 & 100.60 & 99.98 & 99.14 & 99.66 & 1100.46 & 100.99 & 100.36 & 99.87 & 100.69 & 99.88 & 99.36 & 100.74 & 100.02 & 98.59 \\
\hline \multicolumn{17}{|c|}{ Atomic proportions on basis of 6 oxygen atoms } \\
\hline Si & 1.961 & 1.958 & 1.980 & 1.980 & 1.941 & 1.922 & 1.993 & 1.938 & 1.928 & 1.957 & 1.976 & 1.980 & 1.976 & 1.957 & 1.981 & 1.956 \\
\hline $\mathrm{Al}$ & 0.060 & 0.070 & 0.035 & 0.041 & 0.114 & 0.113 & 0.041 & 0.088 & 0.102 & 0.048 & 0.095 & 0.088 & 0.065 & 0.067 & 0.056 & 0.079 \\
\hline $\mathrm{Cr}$ & - & - & - & - & 0.013 & 0.006 & 0.006 & 0.027 & 0.009 & 0.001 & 0.007 & 0.009 & - & 0.011 & - & - \\
\hline $\mathrm{Ti}$ & - & - & - & - & 0.009 & 0.016 & 0.001 & 0.004 & 0.004 & 0.003 & 0.006 & 0.007 & - & 0.008 & - & 0.006 \\
\hline $\mathrm{Fe}$ & 0.118 & 0.183 & 0.075 & 0.078 & 0.145 & 0.191 & 0.112 & 0.122 & 0.149 & 0.201 & 0.189 & 0.182 & 0.160 & 0.227 & 0.171 & 0.216 \\
\hline $\mathrm{Mn}$ & & & & & 0.012 & 0.011 & 0.004 & 0.004 & 0.003 & 0.006 & 0.002 & 0.006 & - & 0.010 & - & - \\
\hline $\mathrm{Mg}$ & 0.950 & 0.880 & 0.932 & 0.919 & 0.802 & 0.762 & 0.911 & 0.896 & 0.911 & 0.868 & 0.889 & 0.822 & 0.870 & 0.840 & 0.881 & 0.852 \\
\hline $\mathrm{Ca}$ & 0.908 & 0.903 & 0.965 & 0.963 & 0.942 & 0.976 & 0.904 & 0.916 & 0.905 & 0.922 & 0.798 & 0.864 & 0.921 & 0.877 & 0.902 & 0.890 \\
\hline $\mathrm{Na}$ & 0.025 & 0.024 & 0.030 & 0.035 & 0.017 & 0.016 & 0.017 & 0.011 & 0.008 & 0.018 & 0.011 & 0.014 & - & - & - & - \\
\hline Total & 4.022 & 4.018 & 4.017 & 4.016 & 3.995 & 4.013 & 3.991 & 4.006 & 4.019 & 4.024 & 3.973 & 3.972 & 3.992 & 3.997 & 3.991 & 3.999 \\
\hline \multicolumn{17}{|c|}{ Atomic proportions $\mathrm{Ca}: \mathrm{Mg}: \mathrm{Fe}$} \\
\hline $\mathrm{Ca}$ & 45.9 & 45.9 & 48.9 & 49.1 & 49.9 & 50.6 & 46.9 & 47.4 & 46.1 & 46.3 & 42.5 & 46.3 & 47.2 & 45.1 & 45.1 & $\overline{43.5}$ \\
\hline $\mathrm{Mg}$ & 48.1 & 44.8 & 47.3 & 46.9 & 42.4 & 39.5 & 47.3 & 47.4 & 46.3 & 43.6 & 47.4 & 44.0 & 44.6 & 43.2 & 8.8 & 11.0 \\
\hline $\mathrm{Fe}$ & 6.0 & 9.3 & 3.8 & 4.0 & 7.7 & 9.9 & 5.8 & 6.3 & 7.6 & 10.1 & 10.1 & 9.7 & 8.2 & 11.7 & 46.1 & 45.4 \\
\hline $\mathrm{Mg} \#$ & 88.9 & 82.8 & 92.6 & 92.2 & 84.5 & 80.0 & 89.1 & 88.0 & 86.0 & 81.2 & 82.5 & 81.9 & 84.5 & 78.7 & 83.7 & 79.8 \\
\hline
\end{tabular}




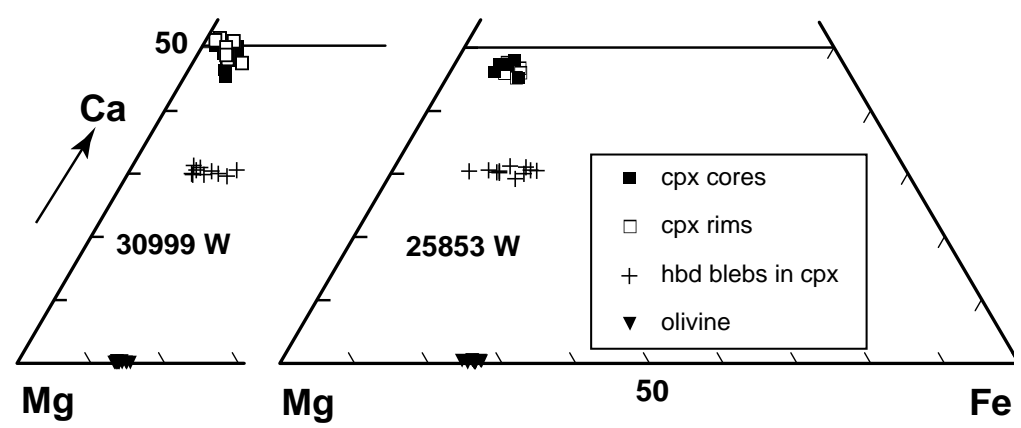

FIG. 6. Concentrations of $\mathrm{Ca}, \mathrm{Mg}$ and total $\mathrm{Fe}$ (atomic proportions) for pyroxene, amphibole, and olivine in wehrlite country-rock next to high-Mg ankaramitic dikes, OU 30999W in the SE contact zone, and OU 25853W at Steep Head, Greenhills Complex.
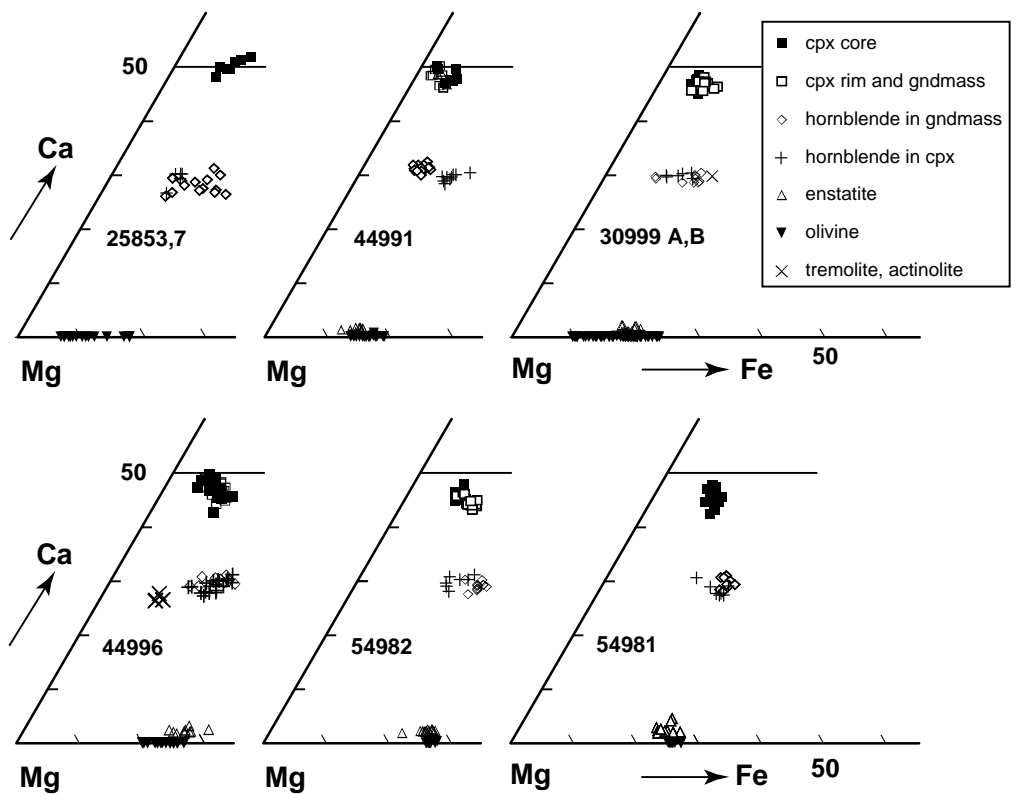

$\mathrm{Mg}$ $\mathrm{Mg}$ $\mathrm{Mg}$

) for pyroxene,

FIG. 7. Concentrations of $\mathrm{Ca}, \mathrm{Mg}$ and total $\mathrm{Fe}$ (atomic proportions) for
amphibole, and olivine in high-Mg ankaramitic dikes, Greenhills Complex

In a few crystals, e.g., OU 44996 and 54982, fine lamellae of orthopyroxene considered to be of exsolution origin, $1-2 \mu \mathrm{m}$ thick, are oriented parallel to diopside $\{100\}$. Phenocrysts and less conspicuously groundmass clinopyroxenes in all analyzed dike-rocks are studded with fine lamellae and broader blebs of pale greenish brown hornblende, typically $10-100 \mu \mathrm{m}$ long, ranging into larger replacements up to $0.5 \mathrm{~mm}$ long (Figs. 3E, F). Shapes are irregular, but the blebs are in optical continuity with each other and, like the finer lamellae, tend to be aligned along $\{100\}$, a plane they share with their pyroxene host. Sections perpendicular to $c$ show a tendency for blebs to be bounded by the amphibole faces $\{110\}$ or $\{010\}$ or both. In contrast to interfaces between host diopside and orthopyroxene lamellae, which are coherent, those with amphibole blebs are in some cases ornamented with minute vacuoles. Their presence suggests the effects of a fluid phase during the replacement process. 


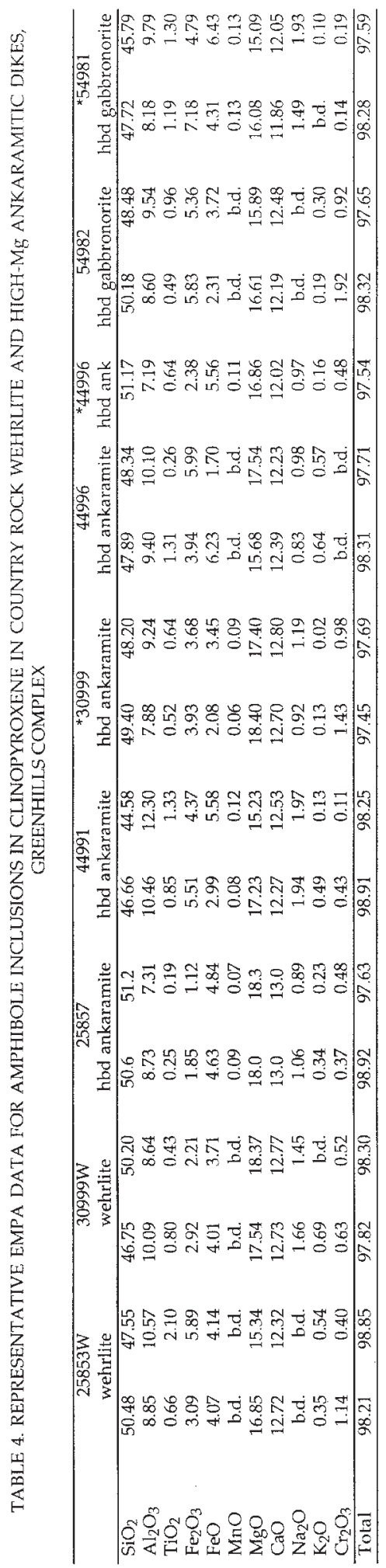

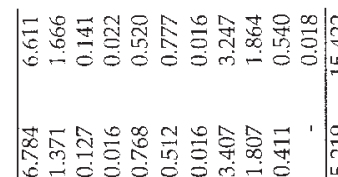

anco

ते 8

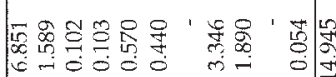

$\sin 2$

in in

20

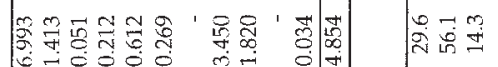

중

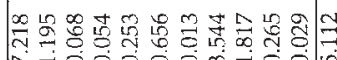

은

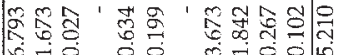

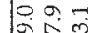

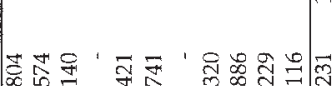

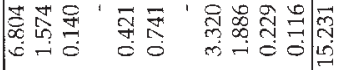

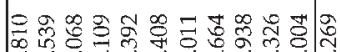

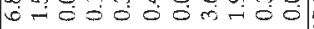

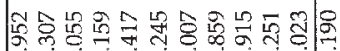

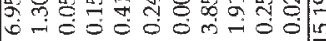

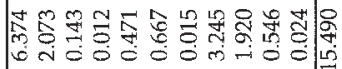

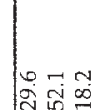

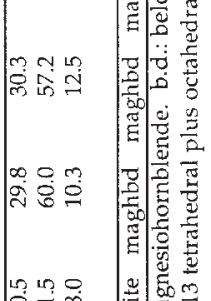

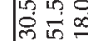
o 40ogosmiogh

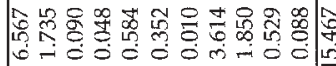

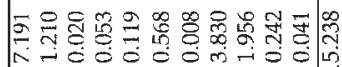
㧒 
Most of the amphibole blebs (Tables 1, 4) consist of magnesiohornblende, but they extend into the composition field of edenite and marginally into that of pargasite as defined by Leake et al. (1997). As shown in Figure 8, $\mathrm{Mg} / \mathrm{Fe}$ values in the blebs other than those in OU 44991 tend to be higher than those of groundmass hornblende, and $\mathrm{Ca} /\left(\mathrm{Mg}+\mathrm{Fe}^{2+}\right)$ in the hornblende is, as always, much lower than in the host clinopyroxene. The $\mathrm{Cr}$ contents of the blebs, although variable, tend to be substantially higher than those of either the diopside hosts or the groundmass hornblende crystals. Thus in OU 30999, seven blebs of hornblende in clinopyroxene average $1.03 \% \mathrm{Cr}_{2} \mathrm{O}_{3}(\sigma=0.22), 13$ host phenocrysts of diopside average $0.30 \% \mathrm{Cr}_{2} \mathrm{O}_{3}(\sigma=0.13)$, and six hornblende grains in the groundmass average only $0.27 \%$ $\mathrm{Cr}_{2} \mathrm{O}_{3}(\sigma=0.20)$. The blebs thus have not crystallized in equilibrium with the late-stage melts; we suggest that the host crystals of diopside are the source of the high $\mathrm{Cr}$, this being partitioned preferentially into the hornblende blebs. On compositional and textural grounds, the hornblende blebs in diopside are interpreted as being essentially synchronous with the brown or brownish green crystals of hornblende in the groundmass, themselves interpreted as late magmatic. Even if the blebs were postmagmatic, their notably high aluminum contents ( ${ }^{\mathrm{IV}} \mathrm{Al}$ in excess of 1 atom per formula unit, $a p f u$ ) indicate formation at temperatures substantially higher than those at which clearly postmagmatic actinolitic amphibole crystallized in some groundmasses and pseudomorphs. Exsolution of a Ca-poor component from diopside could be expected to proceed at the temperatures of crystallization of such hornblende ( $c f$. Nabelek et al. 1987). Penetration by magmatic fluid components along defects in the diopside crystals would allow the necessary introduction of $(\mathrm{OH}), \mathrm{K}, \mathrm{Al}$, and probably some $\mathrm{Na}$ and $\mathrm{Ti}$ for the hornblende-forming reactions. Partitioning of $\mathrm{Ca}$ between diopside and hornblende blebs was accompanied by a net export of $\mathrm{Ca}$. Formation of the hornblende blebs may have contributed to an exsolution process by what might be referred to as reactive exsolution. By this, formation of the blebs resulted in an enhanced $\mathrm{Ca}$ content relative to $\mathrm{Mg}$ and $\mathrm{Fe}$ in the remaining clinopyroxene, much as occurs when enstatite or pigeonite exsolves from augite or diopside where $\mathrm{P}\left(\mathrm{H}_{2} \mathrm{O}\right)$ is low. The electron-microprobe data plotted in Figure 8 may accordingly overestimate the Ca content of the pyroxene grains at the time of initial magmatic crystallization.

Late-magmatic hornblende and bleb-like inclusions of hornblende in clinopyroxene are typical of mafic and ultramafic intrusions crystallizing under conditions of high $\mathrm{P}\left(\mathrm{H}_{2} \mathrm{O}\right)$ in inferred arc environments, as in the Duke Island and other bodies in southeastern Alaska (e.g., Irvine 1967), the Smartville Complex of northern California (Beard \& Day 1988) and innumerable other examples. Reactive exsolution in such cases may be as important as later metamorphic uralitization, with which process it could easily be confused.

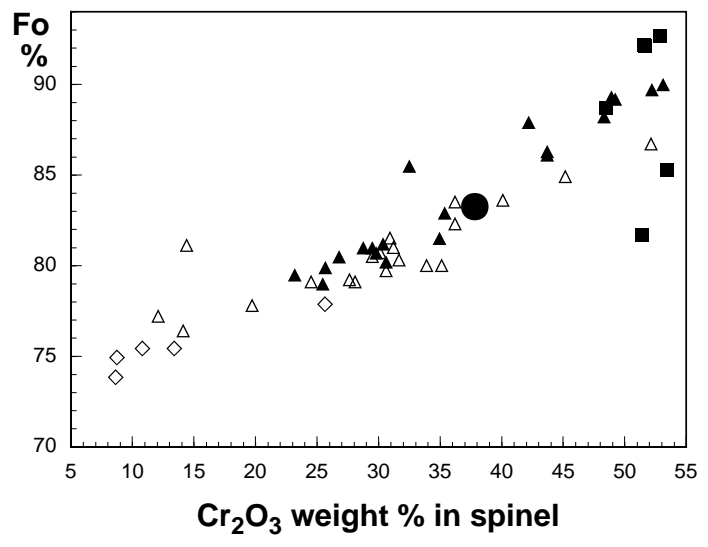

FIG. 8. Relationship between Cr content of spinel inclusions and Fo content adjacent to enclosing olivine, Greenhills high-Mg ankaramitic dikes. Squares: OU 25857; solid triangles: OU 30999 dike center; open triangles: OU 30999 dike margin; diamond: OU 44996; solid circle: average for all analyzed olivine and chromite, OU 44991.

The average composition (Table 1) of groundmass diopside in OU 54981 plots close to the expected position of an $860^{\circ} \mathrm{C}$ isotherm for equilibration with enstatite (Nabelek et al. 1987, Fig. 3), whereas the corresponding averages for OU 44991, 30999, 44996, and 54982 plot close to the expected positions of $750^{\circ}-800^{\circ} \mathrm{C}$ isotherms. However, as discussed above, these compositions may have been affected by continuing exsolution with loss of $\mathrm{Ca}$ relative to $\mathrm{Mg}$ and $\mathrm{Fe}$, and equilibration with the hornblende inclusions.

\section{Enstatite}

Enstatite (Tables 1, 5, Fig. 7) occurs as a granular reaction-rim on olivine in all analyzed rocks except $\mathrm{OU}$ 25857 and as somewhat larger grains in the groundmasses. In most of the dikes, $\mathrm{Fe} / \mathrm{Mg}$ values are in the range of those of the coexisting forsterite crystals, extending to still lower $\mathrm{Fe} / \mathrm{Mg}$, but in OU 44996 a groundmass fractionation trend continues to higher $\mathrm{Fe} / \mathrm{Mg}$ values. The $\mathrm{Ca}$ contents are low, with average $100 \mathrm{Ca} /$ $(\mathrm{Mg}+\mathrm{Fe})$ for groundmass enstatite (Table 1) ranging from 1.2 in the most Mg-rich dike analyzed that contains enstatite, OU 44991, to $2.5 \%$ in the least Mg-rich, OU 54981. For OU 54981, the average composition plots on the $900^{\circ} \mathrm{C}$ isotherm of Nabelek et al. (1987) for equilibration with diopside, whereas the others would plot close to the expected position of an $800^{\circ} \mathrm{C}$ isotherm. These figures give only crude estimates of temperature, because of analytical error in small amounts of $\mathrm{Ca}$, and the close spacing of the calculated isotherms. 
'IABLE 5. REPRLSENTATIVE EMPA DATA FOR ORTHOPYROXENE IN ANKARAMTTIC HIGH-Mg DIKES, GREENHILLS COMPLEX

\begin{tabular}{|c|c|c|c|c|c|c|c|c|c|c|c|}
\hline \multirow[t]{2}{*}{ OU no. } & \multicolumn{2}{|c|}{$4499]$} & \multirow{2}{*}{$\begin{array}{c}30999 \mathrm{~A} \\
\text { *on ol }\end{array}$} & \multicolumn{2}{|c|}{$30999 \mathrm{~B}$} & \multicolumn{2}{|c|}{44996} & \multicolumn{2}{|c|}{54982} & \multicolumn{2}{|c|}{54981} \\
\hline & gndms & gndms & & *gndms & *on ol & gndms & gndms & *in plag & gndms & gndms & gndms \\
\hline $\mathrm{SiO}_{2}$ & 57.78 & 56.96 & 55.3 & 55.1 & 56.2 & 55.26 & 55.25 & 55.04 & 54.89 & 55.06 & 55.73 \\
\hline $\mathrm{Al}_{2} \mathrm{O}_{3}$ & 0.76 & 0.95 & 1.15 & 1.02 & 1.17 & 1.89 & 1.14 & 1.30 & 1.34 & 0.87 & 1.24 \\
\hline $\mathrm{TiO}_{2}$ & b.d. & b.d. & 0.05 & 0.06 & 0.22 & b.d. & b.d. & 0.26 & b.d. & b.d. & 0.20 \\
\hline $\mathrm{FeO}$ & 8.14 & 10.41 & 13.6 & 12.8 & 11.7 & 15.57 & 17.37 & 15.32 & 16.24 & 16.34 & 14.52 \\
\hline $\mathrm{MnO}$ & b.d. & b.d. & 0.33 & 0.33 & 0.28 & b.d. & b.d. & 0.27 & 0.32 & 0.36 & 0.32 \\
\hline $\mathrm{MgO}$ & 33.01 & 32.04 & 29.4 & 29.5 & 30.4 & 27.03 & 26.03 & 26.72 & 26.76 & 26.88 & 27.59 \\
\hline $\mathrm{CaO}$ & 0.66 & 0.64 & 0.67 & 0.87 & 0.67 & 0.97 & 1.06 & 1.12 & 1.10 & 0.96 & 1.10 \\
\hline $\mathrm{Cr}_{2} \mathrm{O}_{3}$ & b.d. & b.d. & 0.05 & 0.03 & 0.00 & b.d. & b.d. & $0.20]$ & b.d. & b.d. & b.d. \\
\hline Total & 100.36 & 101.00 & 100.55 & 99.71 & 100.64 & 100.72 & 100.85 & 100.24 & 100.65 & 100.47 & 100.70 \\
\hline \multicolumn{12}{|c|}{ Atomic proportions on basis of 6 oxygen atoms } \\
\hline $5 i$ & 1.997 & 1.978 & 1.964 & 1.968 & 1.974 & 1.971 & 1.985 & 1.977 & 1.972 & 1.983 & 1.983 \\
\hline $\mathrm{Al}$ & 0.031 & 0.039 & 0.048 & 0.043 & 0.048 & 0.079 & 0.048 & 0.055 & 0.056 & 0.026 & 0.052 \\
\hline $\mathrm{Cr}$ & & - & 0.001 & 0.001 & 0.000 & - & - & 0.006 & - & - & \\
\hline $\mathrm{Ti}$ & - & - & 0.001 & 0.002 & 0.006 & - & - & 0.007 & - & - & 0.005 \\
\hline $\mathrm{Fe}$ & 0.235 & $0.30) 2$ & 0.404 & 0.382 & 0.344 & 0.464 & 0.522 & 0.460 & 0.488 & 0.181 & 0.432 \\
\hline $\mathrm{Mn}$ & - & - & 0.010 & 0.010 & 0.0008 & - & - & 0.008 & 0.010 & - & 0.010 \\
\hline $\mathrm{Mg}$ & 1.700 & 1.659 & 1.556 & 1.570 & 1.591 & 1.437 & 1.394 & 1.430 & 1.433 & 0.872 & 1.463 \\
\hline $\mathrm{Ca}$ & 0.025 & 0.023 & 0.025 & 0.033 & 0.025 & 0.037 & 0.041 & 0.043 & 0.042 & 0.942 & 0.042 \\
\hline Total & 3.988 & 4.001 & 4.009 & 4.009 & 3.996 & 3.988 & 3.990 & 3.986 & 4.001 & 4.004 & 3.987 \\
\hline \multicolumn{12}{|c|}{ Atomic proportion: $\mathrm{Ca}: \mathrm{Mg}: \mathrm{Fe}$} \\
\hline $\mathrm{Ca}$ & 1.2 & 1,2 & 1.3 & 1.7 & 1.3 & 1.9 & 2.1 & 2.2 & 2.2 & 1.9 & 2.2 \\
\hline $\mathrm{Mg}$ & 86.8 & 83.6 & 78.4 & 79.1 & 81.2 & 74.1 & 71.1 & 74.0 & 73.0 & 73.2 & 75.5 \\
\hline $\mathrm{Fe}$ & 12.0 & 15.2 & 20.3 & 19.3 & 17.5 & 24.0 & 26.7 & 23.8 & 24.8 & 25.0 & 22.3 \\
\hline $\mathrm{Mg} \#$ & 87.8 & 84.6 & 79.4 & 80.4 & 82.2 & 75.6 & 72.8 & 75.7 & 74.6 & 74.6 & 77.2 \\
\hline
\end{tabular}

\section{Groundmass and oikocrystic amphibole}

Pigeonite has not been found in any of the dikes. Instead, the crystallization of groundmass enstatite and diopside in the dikes other than OU 25853 was followed by that of amphibole. Pale brownish green to greenish brown in color, this amphibole ranges in composition (Tables 1, 6) from predominant magnesiohornblende into the field of tschermakite (Leake et al. 1997). Similar hornblende forms the almost monomineralic groundmass of the Steep Head hornblende ankaramite dike OU $25853 / 25857$. Electron-microprobe traverses normal to the $c$ axes of hornblende in this body show that the grains become more iron-rich from cores to outer zones without obvious change in color, but in OU 44996 outer greenish zones not only have consistently lower $\mathrm{Al}$ contents, they also have higher $\mathrm{Mg} / \mathrm{Fe}$, a ratio that is still higher in clearly metamorphic actinolitic amphibole in the same rock (Fig. 8). With this exception, Fe/Mg values in the groundmass amphibole crystals and larger oikocrysts are in general greater than in clinopyroxene of the same rocks (Fig. 8), continuing a trend of magmatic fractionation. Reversal of the trend in the latest magmatic amphiboles is attributed to increasing $f\left(\mathrm{O}_{2}\right)$ and crystallization of magnetite.

The average Al content of 60 analyzed possible quench and brownish groundmass hornblende grains in all rocks is $11.22 \% \mathrm{Al}_{2} \mathrm{O}_{3}$, that of 17 greenish outer zones is $7.44 \% \mathrm{Al}_{2} \mathrm{O}_{3}$. Titanium contents are highly variable. In the chilled margin OU 25853 of the Steep Head hornblende ankaramite dike, analyses show 0.14 $1.55 \% \mathrm{TiO}_{2}$, and from the interior of the dike, 0.10-
$1.41 \%$. A similar situation prevails in OU 30999, with an overall range of $0.59-2.12 \% \mathrm{TiO}_{2}$. In both cases the average recorded value in the dike margins is greater than in the dike centers. According to Helz (1973), the Ti content of hornblende tends to increase with increasing temperature of equilibration, and it should decrease with increasing $f\left(\mathrm{O}_{2}\right)$ accompanied by a fall in ${ }^{\mathrm{IV}} \mathrm{Al}$, an effect not shown in the present case. Apart from indicating a lack of equilibrium, the observed $\mathrm{TiO}_{2}$ figures are not adequately explained. In OU 44996, however, a drop from average $1.31 \% \mathrm{TiO}_{2}(\sigma=0.3)$ in 11 compositions of brownish high-Al hornblende (Table 2) to mostly below-EDS detection limits of about $0.2 \%$ in greenish outer zones with lower Al contents, is clearly compatible with declining temperature and increasing $f\left(\mathrm{O}_{2}\right)$ in the latest magmatic and possibly postmagmatic stages.

\section{Plagioclase}

Highly calcic plagioclase occurs across the width of the various dikes except the Steep Head hornblende ankaramite dike, in which it is confined to the selvedges. The modal proportion approaches $9-12 \%$ at the outer border of this dike, decreasing to nil inward over the 5$\mathrm{cm}$ thickness of the selvedge. The grain size here is in tenths of a millimeter at most, the composition is anorthite $\mathrm{An}_{99-94}$ (Table 1), and twinning is according to Carlsbad and albite laws. In the other dikes, calcic plagioclase with an overall range $A n_{95-75}$ accompanies diopside, enstatite, and later hornblende in the groundmass. 
HIGH-Mg ANKARAMITIC DIKES, GREENHILLS COMPLEX, N.Z.

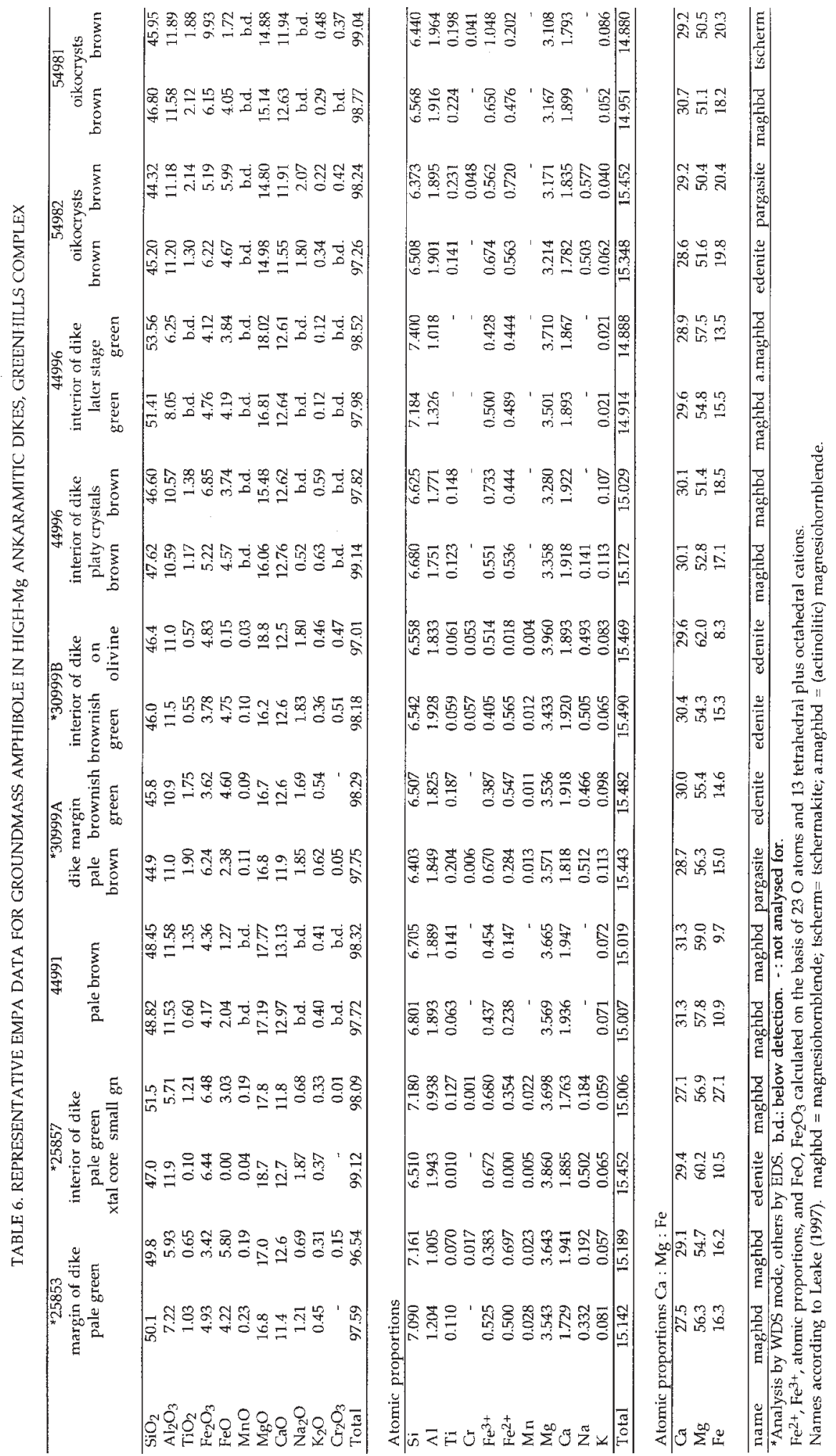




\section{Chromian spinel, magnetite, and ilmenite}

Chromium-rich spinel (Tables 2, 7) occurs as inclusions in phenocrysts of olivine and, to a lesser extent, in phenocrysts of diopside in all the dikes, as well as in the matrix, in which magnetite may also be present. Grain size is typically 20-200 $\mu \mathrm{m}$, some grains reaching 1 $\mathrm{mm}$. The $\mathrm{Cr}$ content of the spinel inclusions correlates closely with the Fo content of the immediately enclosing olivine (Fig. 8). The extent of zoning is slight; the core to rim composition of a typical inclusion in olivine in OU 30999, for example, varies from 35 to $34 \mathrm{wt} \%$ $\mathrm{Cr}_{2} \mathrm{O}_{3}$ only. These facts indicate that the melts were progressively impoverished in $\mathrm{Cr}$ during the crystallization of olivine, and furthermore that grains tended to be trapped shortly after growth, although some were preserved in groundmass of more evolved composition.

Compositions range from chromite with nearly 54 wt $\% \mathrm{Cr}_{2} \mathrm{O}_{3}$, through less $\mathrm{Cr}$-rich chromite and chromian magnetite to essentially $\mathrm{Cr}$-free magnetite, the less $\mathrm{Cr}$ rich examples being characteristic of the less $\mathrm{Mg}$-rich dikes OU 44996, 54982, and 54981 and of the groundmass of the more Mg-rich dikes, such as OU 30999. While olivine, diopside, and chromite were the only phases crystallizing, the Al contents of the melts would have been enhanced, and chromite followed a trend of falling $\mathrm{Cr}$ and increasing $\mathrm{Al}$ (Fig. 9). Peak $\mathrm{Al}$ contents in chromite of about $17 \mathrm{wt} \% \mathrm{Al}_{2} \mathrm{O}_{3}$ were reached with about $37 \% \mathrm{Cr}_{2} \mathrm{O}_{3}$. Subsequently, $\mathrm{Cr}$ and $\mathrm{Al}$ both decline in a series ranging through chromian magnetite to magnetite with simultaneous crystallization of plagioclase and hornblende and increasing substitution by $\mathrm{Fe}^{3+}$.
In keeping with chromian spinel from other volcanic arcs, the Greenhills suite is low in Ti. In many cases the Ti content is even lower than in field AA (Fig. 10) shown by Arai (1992) for arc-derived chromium-rich spinel on a plot of $\mathrm{TiO}_{2}$ versus $\mathrm{Fe \#}$, i.e., $100 \mathrm{Fe}^{3+} /(\mathrm{Cr}+$ $\left.\mathrm{Al}+\mathrm{Fe}^{3+}\right)$. Ti contents are much lower than in field II (Fig. 10) representing intraplate settings, and generally lower than in the small field for MORB rocks shown by Arai (1992) to overlap fields AA and II, with Fe\# less than 10 and $\mathrm{Ti}$ less than $1 \% \mathrm{TiO}_{2}$. With increasing Fe\#, $\mathrm{Ti}$ increases in the spinels of the Greenhills dikes (Fig. 10). The substantial scatter is probably in part the result of incipient exsolution of ilmenite, lamellae of which, only 2-4 $\mu \mathrm{m}$ thick, have been observed in groundmass magnetite in the interior of dike OU 30999 (Table 7). Compositions of coexisting ilmenite - magnetite indicate partial re-equilibration under postmagmatic conditions at about $645^{\circ} \mathrm{C}, \Delta \log f\left(\mathrm{O}_{2}\right)=2.7$ relative to the FMQ buffer (Frost et al. 1988).

It can be shown that on a plot of $\mathrm{Cr} \#, 100 \mathrm{Cr} / \mathrm{Cr}+$ $\mathrm{Al})$ versus $\mathrm{Mg \#}, 100 /\left(\mathrm{Mg}+\mathrm{Fe}^{2+}\right)$, the Greenhills spinelgroup minerals fall in a broad field shown by Kepezhinskas et al. (1993) for various subduction-related suites, including plutons of the North Kamchatka arc and ankaramites from West Epi, Vanuatu.

\section{Whole-Rock Geochemistry and Discussion}

Results of whole-rock major and minor element analyses of the dike rocks are presented in Table 8. Particularly striking are the high $\mathrm{Mg}$ contents, ranging from $28.3 \mathrm{wt} \% \mathrm{MgO}$ on an anhydrous basis in the central zone (OU 25857) of one Steep Head dike to $10.6 \% \mathrm{MgO}$ in the marginal zone (OU 54981a) of another.

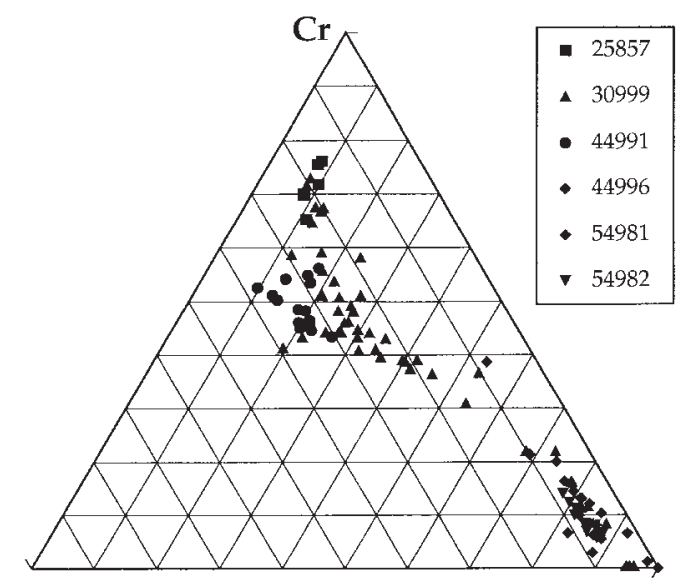

Al $\mathrm{Fe}^{3+}$

FIG. 9. Proportions of $\mathrm{Fe}^{3+}, \mathrm{Al}$ and $\mathrm{Cr}$ in chromite, chromian magnetite, and magnetite, Greenhills high-Mg ankaramitic dikes.
TABLE 7. REPRESENIAITVE EMPA DATA FOR GROLNDMASS CIIROMIIE, CHROMLA MACNETTE C Cr-POOR MAGNETTE, AND 4- $\mathrm{kM}$ ILMENTTE EXSOLUTION LAMEL LAE, HIGH-Mg NKARAMITIC DIKES, GREENI IILLS COMPLEX

\begin{tabular}{|c|c|c|c|c|c|c|c|c|}
\hline OC no. & 44991 & ${ }^{* 30999}$ & +30999 & 44996 & 54982 & 54981 & $\star 30999$ & $\times 3099$ \\
\hline & & & & & & & host mt & il in $m$ \\
\hline $5 \mathrm{SO}_{2}$ & 0.95 & 0.13 & 0.16 & & 1.34 & 1.36 & 0.07 & \\
\hline $\mathrm{TiO}_{2}^{2}$ & 0.59 & 2.11 & 4.31 & 0.84 & 2.34 & 2.82 & 2.39 & \\
\hline $\mathrm{Al}_{2} \mathrm{O}_{3}$ & 17.58 & 2.62 & 2.05 & $16 \%$ & 2.12 & 2.71 & 1.74 & \\
\hline $\mathrm{Cr}_{2} \mathrm{O}_{3}$ & 36.88 & 7.39 & 6.67 & 6.73 & 4.78 & 3.48 & 0.29 & \\
\hline $\mathrm{V}_{2} \mathrm{O}_{3}$ & & 1.39 & $0.8 i$ & & & & 0.92 & \\
\hline $\mathrm{Fe}_{2} \mathrm{O}_{3}$ & 10.79 & 52.57 & 50.07 & 58.58 & 54.16 & 54.40 & 61.39 & \\
\hline $\mathrm{FeO}$ & 29.34 & 31.99 & 33.54 & 3119 & 34.68 & 34.12 & 32.60 & \\
\hline $\mathrm{MnO}$ & b.d. & 0.22 & 0.31 & 0.08 & bd. & 0.39 & 0.10 & \\
\hline $\mathrm{MgO}$ & 4.86 & 0.59 & 0.72 & 0.51 & 0.36 & 1.03 & 0.48 & \\
\hline $\mathrm{CaO}$ & b.d. & 0.25 & 0.27 & b.d. & 0.33 & b.d. & 0.13 & \\
\hline $\mathrm{NiO}$ & b.d. & 0.19 & 0.17 & 0.16 & b.d. & b.d. & 0.18 & \\
\hline Total & 100.99 & 99.45 & 99.077 & 94.83 & 100.41 & 100.31 & 100.29 & \\
\hline
\end{tabular}

\begin{tabular}{|c|c|c|c|c|c|c|c|c|}
\hline $\mathrm{Si}$ & 0.25 & 0.04 & 0.05 & & 0.40 & 0.40 & 0.02 & 0.00 \\
\hline $\mathrm{Ti}$ & 0.12 & 0.48 & 0.98 & 0.20 & 0.53 & 0.63 & 0.54 & 0.89 \\
\hline Al & 5.45 & 0.93 & 0.73 & 0.60 & 0.85 & 0.95 & 0.62 & \\
\hline $\mathrm{Cr}$ & 7.68 & 1.76 & 1.60 & 1.61 & 1.1 .3 & 0.82 & 0.07 & \\
\hline $\bar{y}$ & & 0.34 & 0.19 & - & - & - & 0.22 & 0.07 \\
\hline $\mathrm{Fe}^{3+}$ & 2.14 & 11.93 & 11.42 & 13.38 & 12.17 & 12.17 & 13.97 & 0.17 \\
\hline $\mathrm{Fe}^{2+}$ & 6.46 & 8.07 & 8.50 & 791 & 8.66 & 8.48 & 8.24 & 0.737 \\
\hline $\mathrm{Mn}_{\mathrm{n}}$ & - & 0.06 & 0.08 & 0.02 & & 0.10 & 0.03 & 0.022 \\
\hline $\mathrm{Mg}$ & 1.41 & 01.27 & 0.33 & 0.23 & 0.16 & 0.46 & \{\}$, 21$ & \\
\hline $\mathrm{Ca}$ & - & 0.08 & 0.09 & & 0.11 & - & 0.04 & \\
\hline $\mathrm{Ni}$ & - & 0.05 & 0.04 & 0.04 & - & - & 0.04 & \\
\hline
\end{tabular}

$\mathrm{FeO}, \mathrm{F}_{2} \mathrm{O}_{3}$, and atomic proportions are calculated on the basis of 24 cations and $32 \mathrm{O}$ aloms for spincls, and 2 cations and 30 atoms for ilmerite

b.d. below detection limits. - not analysed for, or for atomic propurtiuns tate be below detertion limits 


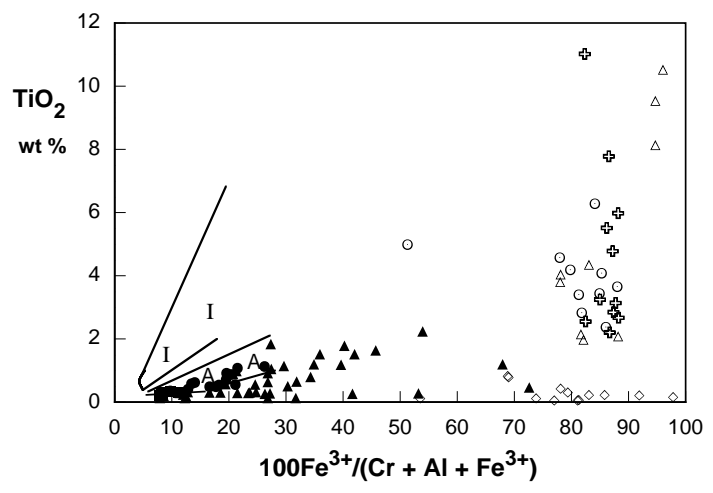

FIG. 10. Relationship between $\mathrm{TiO}_{2}$ (weight $\%$ ) and $\mathrm{Fe \#} \mathrm{=}$ $100 \mathrm{Fe}^{3+} /\left(\mathrm{Cr}+\mathrm{Al}+\mathrm{Fe}^{3+}\right)$ for chromite and chromian magnetite in Greenhills high-Mg ankaramitic dikes (symbols as for Fig. 9) compared with fields for chromian spinel in intraplate magmas (I-I) and arc magmas (A-A) according to Arai (1992).

\section{Relationship to arc-ankaramites, komatiites, and picrites}

The significance of any similarity in mode of occurrence of the high-Mg dikes with lamprophyres as normally understood is negated by extremely low alkali contents, especially $\mathrm{K}$, and their general mineralogy.

The mineralogy of the dikes closely matches that of the enclosing wehrlites, as shown, for example, by comparison of mafic minerals of dike OU 44991 (Fig. 7) with those of wehrlite 30999W (Fig. 6), and dikes OU 54981, 54982 (Fig. 7) with those of wehrlite 25853W

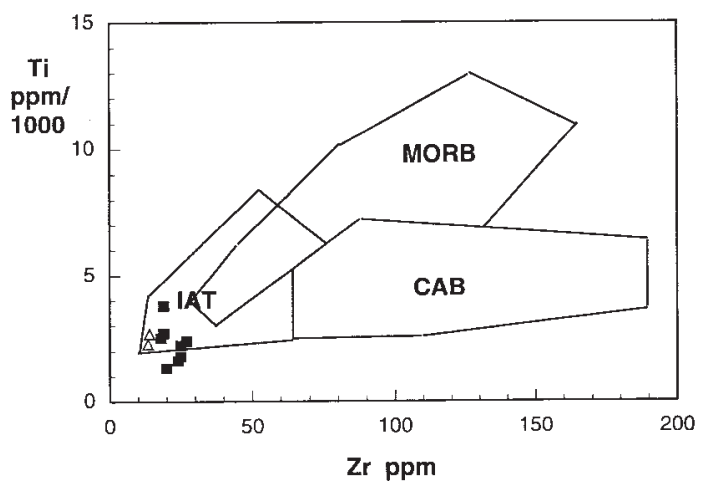

FIG. 11. Ti-Zr plot for Greenhills high-Mg dikes (filled squares) and arc-ankaramites from Epi, Vanuatu (Barsdell \& Berry 1990) (open triangles), with fields of island-arc low-potassium tholeiites (IAT), mid-ocean ridge basalt (MORB), and calc-alkaline basalts (CAB) after Pearce \& Cann (1973).
(Fig. 6). Both the mafic minerals and the highly calcic plagioclase in the dikes match those found in the layered series of the Greenhills Complex, which ranges from dunite, through wehrlite, eucritic gabbro and allivalite, to hornblende gabbronorite. We conclude that the dikes represent liquids in various stages of evolution that have evolved in, or replenished, the magma chamber represented by the layered series.

As discussed above, geochemical features of the clinopyroxene and chromian spinel in the dikes are typical of other subduction-related suites. This affinity is also indicated in whole-rock $\mathrm{Ti}-\mathrm{Zr}$ and $\mathrm{V}-\mathrm{Ti}$ diagrams (Figs. 11, 12), in which the Greenhills rocks plot either within the fields outlined by Pearce \& Cann (1973) and Shervais (1982) for island-arc low-potassium tholeiites sampled by them, or narrowly extend those fields to more extreme compositions. It is noteworthy that arcankaramites from the island of Epi in Vanuatu (e.g., Table 9, no. 2) described by Barsdell (1988), Barsdell \& Berry (1990), and Della-Pasqua \& Varne (1997) have compositions very similar to the less extreme $\mathrm{Mg}$-rich Greenhills dikes and occupy similar fields in Figures 11 and 12 , and also in $\mathrm{Ni}-\mathrm{MgO}$ and $\mathrm{Cr}-\mathrm{MgO}$ plots, discussed below.

The high $\mathrm{Mg}$ contents invite comparison with komatiites and certain picrites as well as with ankaramites and clinopyroxene-rich gabbros of islandarc settings such as those of Vanuatu and of Smartville, California (Beard \& Day 1988). Low REE abundances (Table 10, Fig. 13A) in the high-Mg Greenhills dikes, less than twice that of primitive mantle of Sun \&

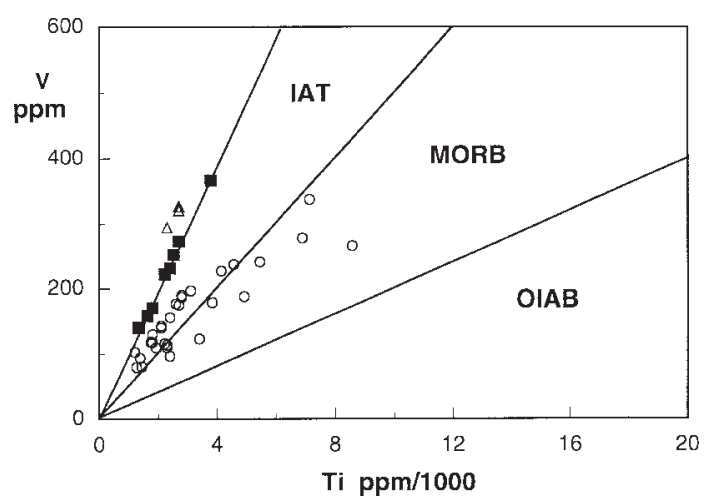

FIG. 12. V-Ti plot for Greenhills high-Mg dikes and arcankaramites from Epi, Vanuatu (Barsdell \& Berry 1990), with fields of island-arc tholeiites (IAT), mid-ocean ridge basalt (MORB) and ocean-island and alkaline basalts (OIAB), after Shervais (1982). The symbols are as in Figure 11. Also shown as open circles: representative peridotitic and basaltic komatiites from Onverwacht Group, South Africa (Jahn et al. 1982) and from Belingwe, Rhodesia, Western Australia, and Ontario, Canada (Nesbitt et al. 1979, Nisbet et al. 1987). 
TABLE 8. ANALYTICAL DATA FOR HIGH-Mg ARC ANKARAMITIC DIKES, GREENHILLS COMPLEX

\begin{tabular}{|c|c|c|c|c|c|c|c|c|}
\hline \multirow[t]{2}{*}{ OU No. } & \multicolumn{2}{|c|}{$25857 / 25853$} & \multirow{2}{*}{$\begin{array}{c}44991 \\
\text { interior }\end{array}$} & \multirow{2}{*}{$\begin{array}{c}30999 \\
\text { interior }\end{array}$} & \multirow{2}{*}{$\begin{array}{c}44996 \\
\text { interior }\end{array}$} & \multirow{2}{*}{$\begin{array}{c}54982 \\
\text { interior }\end{array}$} & \multicolumn{2}{|c|}{$54981 / 54981 a$} \\
\hline & centre & margin & & & & & centre & margin \\
\hline $\mathrm{SiO}_{2}$ & 43.84 & 47.69 & 45.93 & 46.20 & 48.03 & 47.36 & 47.93 & 46.73 \\
\hline $\mathrm{TiO}_{2}$ & 0.22 & 0.37 & 0.27 & 0.30 & 0.40 & 0.42 & 0.45 & 0.63 \\
\hline $\mathrm{Al}_{2} \mathrm{O}_{3}$ & 5.21 & 8.95 & 5.83 & 6.70 & 9.60 & 10.12 & 11.48 & 14.27 \\
\hline $\mathrm{Fe}_{2} \mathrm{O}_{3}{ }^{*}$ & 10.04 & 9.40 & 10.89 & 10.71 & 10.72 & 11.59 & 11.55 & 11.24 \\
\hline $\mathrm{MnO}$ & 0.18 & 0.15 & 0.19 & 0.19 & 0.19 & 0.21 & 0.21 & 0.18 \\
\hline $\mathrm{MgO}$ & 26.79 & 16.98 & 25.67 & 23.89 & 16.84 & 16.36 & 13.97 & 10.56 \\
\hline $\mathrm{CaO}$ & 7.58 & 12.56 & 9.29 & 9.77 & 12.18 & 12.81 & 13.33 & 15.10 \\
\hline $\mathrm{Na}_{2} \mathrm{O}$ & 0.53 & 1.05 & 0.61 & 0.77 & 0.95 & 0.67 & 0.76 & 0.88 \\
\hline $\mathrm{K}_{2} \mathrm{O}$ & 0.14 & 0.32 & 0.10 & 0.15 & 0.20 & 0.03 & 0.04 & 0.03 \\
\hline $\mathrm{P}_{2} \mathrm{O}_{5}$ & 0.03 & 0.04 & 0.03 & 0.03 & 0.04 & 0.02 & 0.02 & 0.02 \\
\hline L.O.I. & 4.64 & 0.99 & 0.58 & 0.75 & 0.49 & 0.21 & 0.35 & 0.51 \\
\hline Total & 99.20 & 98.50 & 99.39 & 99.46 & 99.64 & 99.80 & 100.09 & 100.15 \\
\hline $\mathrm{MgO}$, anhydrous & 28.3 & 17.4 & 26.0 & 24.2 & 17.0 & 16.4 & 14.0 & 10.6 \\
\hline $100 \mathrm{Mg} /(\mathrm{Mg}+0.8 \mathrm{Fe})$ & e) 87 & 82 & 85 & 85 & 80 & 78 & 75 & 70 \\
\hline $\mathrm{CaO} / \mathrm{Al}_{2} \mathrm{O}_{3}$ & 1.45 & 1.40 & 1.59 & 1.46 & 1.27 & 1.27 & 1.16 & 1.06 \\
\hline
\end{tabular}

CIPW Norm components, normalized to $100 \%$, volatile-free, $\mathrm{Fe}_{2} \mathrm{O}_{3} / \mathrm{FeO}=0.2$

$\begin{array}{lcccccccr}\text { Ci } & 22.02 & 35.76 & 26.77 & 27.56 & 31.65 & 31.72 & 31.18 & 32.80 \\ \text { hy } & 14.68 & 10.53 & 12.46 & 10.98 & 15.69 & 16.80 & 19.21 & 9.32 \\ \text { ol } & 42.55 & 20.20 & 38.69 & 36.11 & \mathbf{1 8 . 2 7} & \mathbf{1 7 . 2 5} & 11.22 & 11.04 \\ \text { Ol (mol) } & \text { Fo87 } & \text { Fo83 } & \text { Fo86 } & \text { Fo85 } & \text { Fo81 } & \text { Fo79 } & \text { Fo76 } & \text { Fo72 }\end{array}$

\begin{tabular}{|c|c|c|c|c|c|c|c|c|}
\hline $\mathrm{Sr}$ & 44 & 99 & 70 & 81 & 152 & 132 & 155 & 200 \\
\hline $\mathrm{Rb}$ & ${ }^{*} 1.04$ & $* 1.02$ & 1 & 2 & 2 & b.d. & b.d. & b.d. \\
\hline $\mathrm{Ba}$ & 31 & 43 & 23 & 40 & 39 & 9 & 20 & 11 \\
\hline Th & $* 0.35$ & ${ }^{*} 0.30$ & b.d. & $* 0.15$ & b.d. & b.d. & b.d. & b.d. \\
\hline U & b.d. & 1 & 1 & 1 & 1 & b.d. & 1 & 2 \\
\hline $\mathrm{Ta}$ & ${ }^{*} 0.04$ & ${ }^{*} 0.05$ & - & ${ }^{*} 0.1$ & - & - & - & - \\
\hline $\mathrm{Nb}$ & ${ }^{*} 0.41$ & ${ }^{*} 0.62$ & - & - & - & - & - & - \\
\hline $\mathrm{Zr}$ & 20 & 25 & 24 & 25 & 27 & 18 & 19 & 19 \\
\hline Hf & ${ }^{*} 0.45$ & ${ }^{*} 0.57$ & - & ${ }^{*} 0.49$ & - & - & - & - \\
\hline Y & 4 & 8 & 6 & 7 & 9 & 8 & 10 & 10 \\
\hline $\mathrm{Ga}$ & 6 & 9 & 7 & 8 & 10 & 10 & 12 & 14 \\
\hline V & 140 & 222 & 158 & 171 & 231 & 252 & 273 & 366 \\
\hline $\mathrm{Ni}$ & 516 & 231 & 626 & 566 & 293 & 233 & 184 & 83 \\
\hline $\mathrm{Cr}$ & 1725 & 1505 & 1526 & 1531 & 1012 & 954 & 683 & 189 \\
\hline $\mathrm{Cu}$ & 7 & 16 & 28 & 54 & 67 & 87 & 72 & 231 \\
\hline $\mathrm{Pb}$ & 4 & 4 & 2 & 3 & 6 & 2 & 4 & 3 \\
\hline Zn & 63 & 54 & 59 & 61 & 62 & 68 & 67 & 59 \\
\hline $\mathrm{La}$ & ${ }^{*} 1.21$ & ${ }^{*} 1.30$ & 5 & 2 & 4 & 3 & b.d. & 3 \\
\hline $\mathrm{Ce}$ & $* 2.76$ & $* 3.202$ & b.d. & $* 2.33$ & 3 & 3 & 4 & 4 \\
\hline $\mathrm{Pr}$ & $* 0.45$ & ${ }^{*} 0.50$ & - & - & - & - & - & - \\
\hline Nd & $* 2.21$ & $* 2.73$ & - & ${ }^{*} 1.77$ & 5 & 3 & 5 & 3 \\
\hline $\mathrm{S} m$ & ${ }^{*} 0.82$ & ${ }^{*} 1.03$ & - & ${ }^{*} 0.7$ & - & - & - & - \\
\hline $\mathrm{Eu}$ & ${ }^{*} 0.31$ & ${ }^{*} 0.34$ & - & ${ }^{*} 0.29$ & - & - & - & - \\
\hline Gd & $* 1.05$ & ${ }^{*} 1.28$ & - & *b.d. & - & - & - & - \\
\hline $\mathrm{Tb}$ & ${ }^{*} 0.19$ & ${ }^{*} 0.23$ & & ${ }^{*} 0.19$ & & & & \\
\hline Dy & $* 1.28$ & ${ }^{*} 1.37$ & - & - & - & $\begin{array}{lll}- & \\
-1\end{array}$ & - & - \\
\hline Ho & ${ }^{*} 0.28$ & ${ }^{*} 0.33$ & - & - & - & - & - & - \\
\hline $\mathrm{Er}$ & ${ }^{*} 0.89$ & ${ }^{*} 1.01$ & - & - & - & - & - & - \\
\hline $\mathrm{Tm}$ & $* 0.13$ & ${ }^{*} 0.15$ & - & - & - & - & - & - \\
\hline $\mathrm{Yb}$ & ${ }^{*} 0.83$ & ${ }^{*} 1.04$ & - & ${ }^{*} 0.78$ & - & - & - & - \\
\hline $\mathrm{Lu}$ & ${ }^{*} 0.13$ & ${ }^{*} 0.15$ & - & ${ }^{*} 0.14$ & - & - & - & - \\
\hline
\end{tabular}

b.d.: below detection. - : not analysed for.

* Analysis by ICP for OU 25857 and 25853, INNA for OU 30999, all others by XRF.

** Total $\mathrm{Fe}$ as $\mathrm{Fe}_{2} \mathrm{O}_{3}$. 
TABLE 9. ANALYTICAL DATA FOR HIGH-Mg ROCKS THAT ARE COMPARED WITH THE ANKARAMITIC DIKES, GREENHILLS COMPLEX

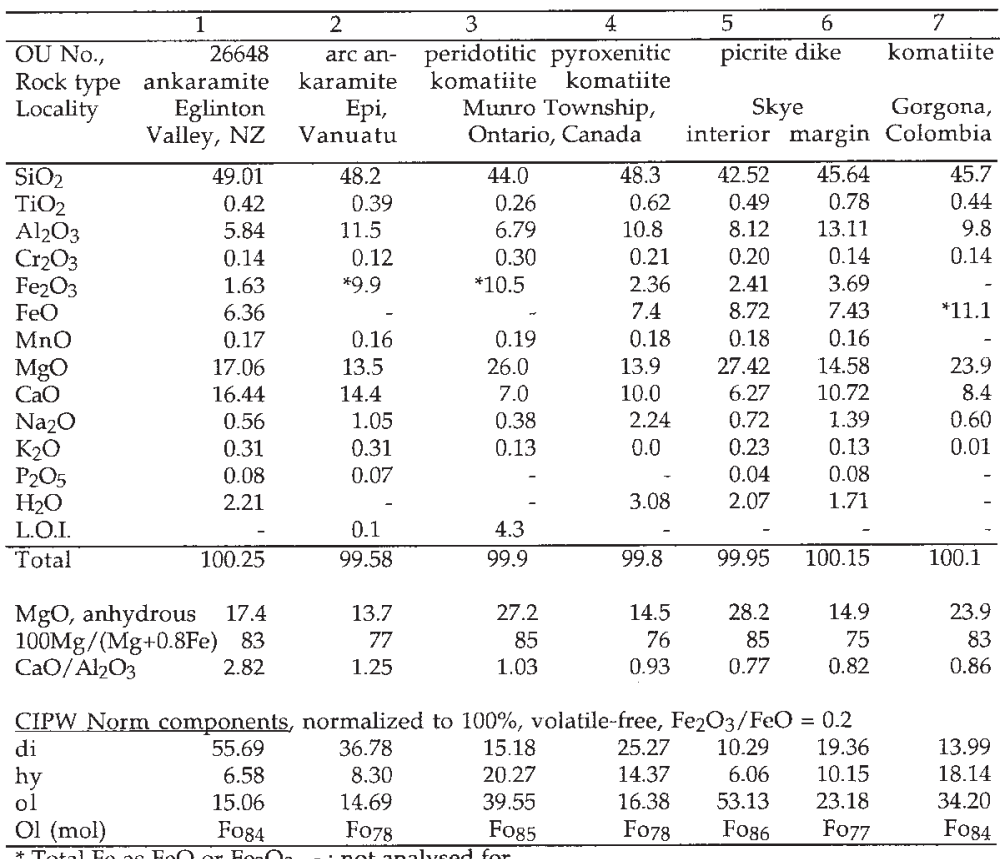

* Total $\mathrm{Fe}$ as $\mathrm{FeO}$ or $\mathrm{Fe}_{2} \mathrm{O}_{3}$. - : not analysed for

1: Brook Street Terrane, Williams \& Smith (1979). Total includes $\mathrm{CO}_{2} 0.02 \% ; \mathrm{Cr}_{2} \mathrm{O}_{3}$ from Cr, reported as 990 ppm.

2: Barsdell \& Berry (1990). $\mathrm{Zr} 13.5$ ppm, V 295 ppm; $\mathrm{Cr}_{2} \mathrm{O}_{3}$ from $\mathrm{Cr}$, reported as $820 \mathrm{ppm}$.

3, 4: Arth et al. (1977). Total for \#3 includes $\mathrm{NiO} 0.05 \%$, and for \#4, $\mathrm{NiO} 0.01 \%$ and $\mathrm{CO}_{2} 0.74 \%$.

5, 6: Gibb (1968, p. 428). Totals include $\mathrm{CO}_{2} 0.56 \%, 0.59 \%$ respectively.

7: Aitken \& Echeverria (1984, Table 5, \#156).

McDonough (1989), indicate a primitive nature. The same applies to very highly magnesian "picrite basalt" flows from a Triassic-Jurassic island-arc system at Kamloops Lake, British Columbia (Fig. 13B), which contain $34-37 \% \mathrm{MgO}$ on a volatile-free basis (Russell \& Snyder 1997). Arc-ankaramite eruptive rocks in the Brook Street Terrane, Eglinton Valley, New Zealand and from Epi (Barsdell \& Berry 1990) have broadly similar patterns slightly enriched in the light REE, and picrites from the Hebridean Province of Scotland, still more so (Kent 1995). Some komatiites (Fig. 13C) give similar flat, low-REE patterns, but others are moderately enriched or impoverished in light REE (e.g., Arth et al. 1977, Jahn et al. 1982).

In the Greenhills dikes here described, $\mathrm{CaO} / \mathrm{Al}_{2} \mathrm{O}_{3}$ is consistently greater than one (Table 8), a feature used by Della-Pasqua \& Varne (1997) to distinguish primitive arc-ankaramite from picrite. Examples of the latter are provided by a highly magnesian flow-differentiated dike in Skye (Gibb 1968, and Table 9, anal. 5 and 6) in which this ratio is $0.77-0.82$, and by other representative picritic "magnesian basalts" from the same province (Kent 1995) in which $\mathrm{CaO} / \mathrm{Al}_{2} \mathrm{O}_{3}$ ranges from 0.59 to 0.72 . In komatiites, $\mathrm{CaO} / \mathrm{Al}_{2} \mathrm{O}_{3}$ is commonly close to unity, but in many cases it is less than one, as in Table 9 , columns 4 and 7 , and in other cases it is higher, for example, 1.56 in a peridotitic komatiite from the Theespruit Formation of the Onverwacht Group, South Africa (Jahn et al. 1982).

The authors of the Basaltic Volcanism Study Project (BVSP 1981) showed that $\mathrm{Ni} / \mathrm{MgO}$ values in typical komatiites fall between lines B and D in Figure 14. The fractionation of olivine causes evolution along gently curving paths reaching line $\mathrm{A}$ at about $15 \%$ or less $\mathrm{MgO}$ in the case of some basaltic members of komatiitic suites such as the Onverwacht Group of South Africa (Jahn et al. 1982). The Greenhills high-Mg dikes plot with arc ankaramites from D'Urville Island and those of West Epi in a gentle curve on and below line A (Fig. 14). Olivine fractionation from the extremely Mg-rich "picrites" of Kamloops Lake, British Columbia, interpreted here as arc-ankaramites, could be expected to generate a course close to the Greenhills arc-ankaramite trend. $\mathrm{Cr} / \mathrm{MgO}$ values are similarly higher in representative komatiites than in arc-ankaramites. 

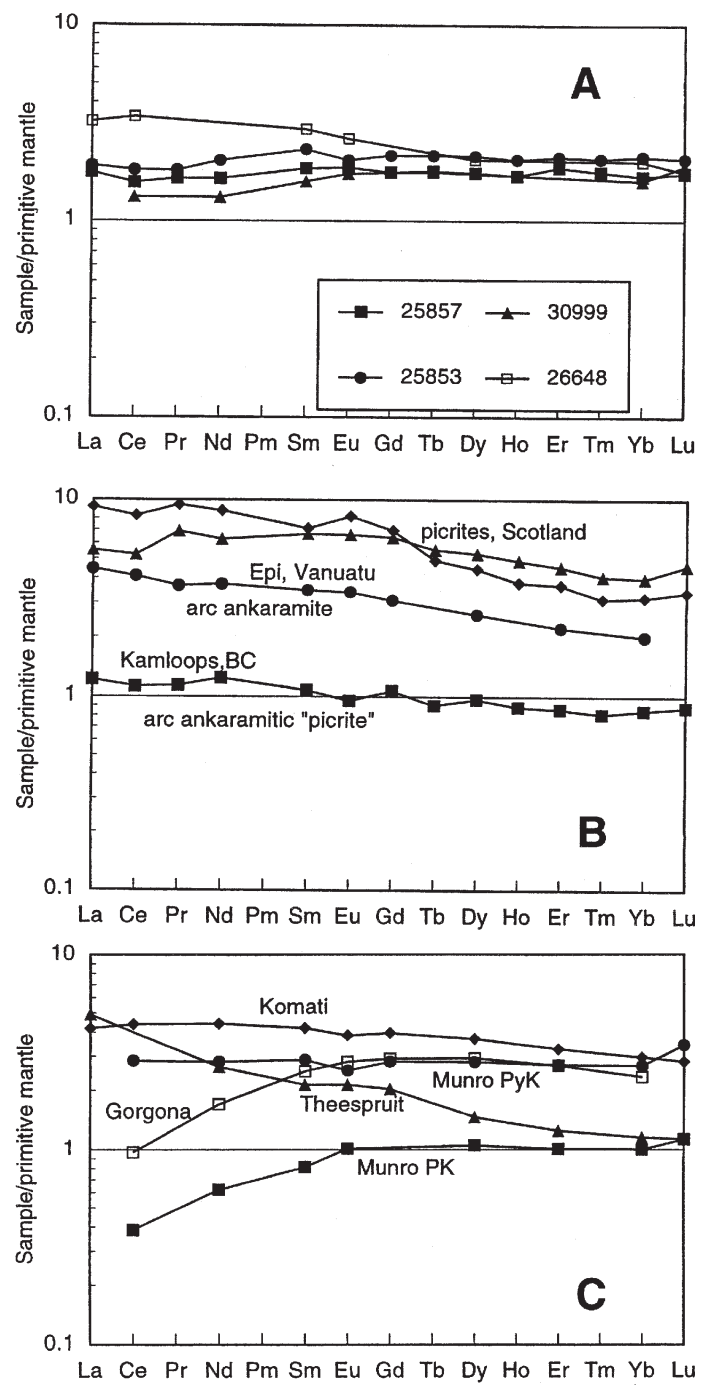

FIG. 13. REE in Greenhills dikes and other high-Mg rocks normalized to primitive mantle of Sun \& McDonough (1989). A. Brook Street Terrane. Greenhills high-Mg ankaramitic dikes, OU 25853 (rim), OU 25857 (core) and OU 30999 (Table 8); also, Eglinton Valley ankaramite OU 26648 (Table 9, \#1). B. Arc-ankaramite, Epi, Vanuatu (Table 9,\#2); ankaramitic "picrite", Kamloops Lake, British Columbia (average of $4,35.5 \% \mathrm{MgO}, \mathrm{CaO} / \mathrm{Al}_{2} \mathrm{O}_{3}=1.56$, Russell \& Snyder 1997); picrites, North Mull and South Harris, Scotland (Kent 1995). C. Komati and Theespruit: basaltic komatiite and peridotitic komatiite with 13.12 and $31.34 \% \mathrm{MgO}$, and $\mathrm{CaO} / \mathrm{Al}_{2} \mathrm{O}_{3}$ of 1.00 and 1.56 , respectively, Onverwacht Group, South Africa (Jahn et al. 1982); Munro PK, Munro PyK: peridotitic komatiite and pyroxenitic komatiite (Table 9, \#4, 5), Munro Township, Ontario; Gorgona: komatiite, Gorgona Island, Colombia, $23.9 \% \mathrm{MgO}, \mathrm{CaO} / \mathrm{Al}_{2} \mathrm{O}_{3}=0.86$ (Aitken \& Echeverría 1984).

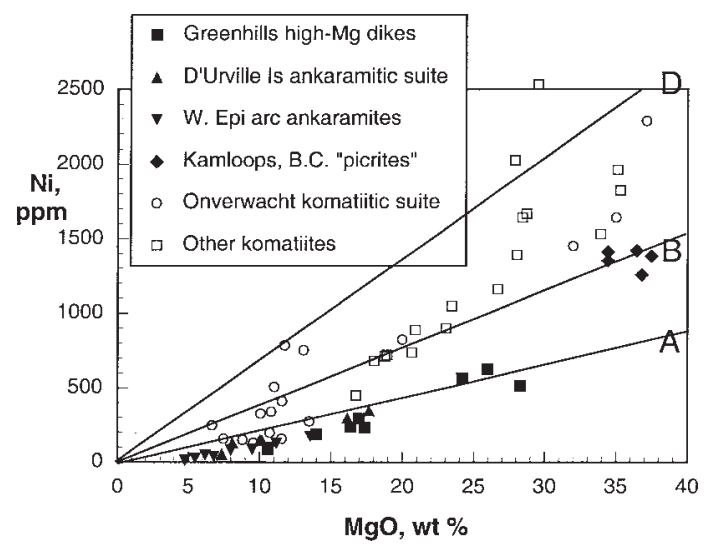

FIG. 14. $\mathrm{MgO} / \mathrm{Ni}$ relationships for Greenhills high-Mg arc ankaramitic dikes and representatives of: ankaramitic suite volcanic rocks from D'Urville Island, Brook Street Terrane, New Zealand (Sivell \& Rankin 1983), arcankaramitic suite of Epi, Vanuatu (Barsdell \& Berry 1990); arc-ankaramitic "picrites" of Kamloops Lake, British Columbia (Russell \& Snyder 1997), komatiitic suite, Onverwacht Group, South Africa (Jahn et al. 1982), komatiites from Rhodesia, West Australia, and Munro Township, Ontario (Nesbitt \& Sun 1976, Nesbitt et al. 1979). See text.

Thus, in spite of some chemical analogies that the more Mg-rich Greenhills dikes show with komatiites, the latter are distinguished by commonly having lower $\mathrm{CaO} / \mathrm{Al}_{2} \mathrm{O}_{3}$ values, and by higher $\mathrm{Ni} / \mathrm{Mg}, \mathrm{Cr} / \mathrm{Mg}$, and $\mathrm{Ti} / \mathrm{V}$.

Contents of high-field-strength elements in the Greenhills dikes are low, mostly less than double those of primitive mantle (Sun \& McDonough 1989). As expected in arc-related volcanism (Pearce 1983), values for $\mathrm{Nb}$ and $\mathrm{Ti}$ are low in multi-element distribution diagrams, a feature also shown by $\mathrm{P}$, whereas the large-ion lithophile elements provide a humped peak, which, however, reaches no more then ten times primitive mantle (Fig. 15). As expected, the phenocryst-free dike margin OU 25853 is enriched in most elements relative to its highly magnesian, olivine-charged interior OU 25857. Surprisingly, the analyzed dikes with the lowest $\mathrm{Mg}$ and highest Al contents (OU 54981, 54981a, and 54982, Table 8), have the lowest values for $\mathrm{K}, \mathrm{Ba}$, and $\mathrm{P}$, with $\mathrm{Rb}$ below detection. Primary phases in these dikes are little altered, and so their low contents of mobile elements cannot be due to preferential loss during secondary alteration. This finding implies in turn that these dikes are not simple fractionates of the more $\mathrm{Mg}$-rich melts.

Ankaramites are usually described as containing abundant phenocrysts of clinopyroxene as well as less 


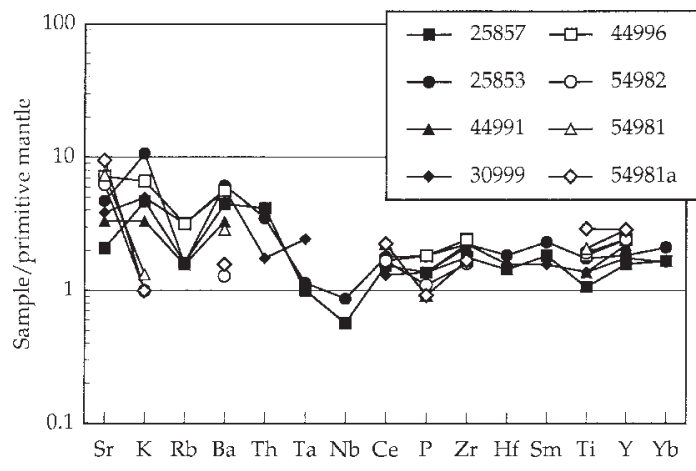

FIG. 15. Multi-element distribution patterns for high-Mg ankaramitic dikes, Greenhills Complex, normalized to primitive mantle of Sun \& McDonough (1989). Data as in Table 9.

abundant olivine. Historically, the term referred to rocks of basanitic alkaline affinity (Le Maitre 1989), but its extension to alkali-poor rocks with similar phenocrystic assemblages in arc-tholeiitic suites is well established. Thus Barsdell \& Berry (1990) used the term arc-ankaramite for primitive basaltic rocks of volcanic arcs, whether tholeiitic, calc-alkaline, or alkaline, but with high $\mathrm{Mg}$-number, clinopyroxene phenocrysts in excess of olivine, and specifically including low-K types. Some of the Greenhills dike rocks meet these criteria as well as having $\mathrm{CaO} / \mathrm{Al}_{2} \mathrm{O}_{3}$ in excess of one. However, the most magnesian examples contain normative and modal olivine in excess of clinopyroxene, while also having the highest values of $\mathrm{CaO} / \mathrm{Al}_{2} \mathrm{O}_{3}, 1.45-1.56$. In light of the tectonic setting, very low $\mathrm{K}$ content and other characteristics, the Greenhills suite can be described as of primitive, arc-tholeiitic nature. Even where quenched, almost phenocryst-free, and consisting of almost monomineralic hornblende, the high-Mg dike rocks here described with $10-28 \% \mathrm{MgO}$ meet the chemical criteria for ankaramites. Chemically, they are tholeiitic arc-ankaramites.

\section{Hydrous nature of the melt}

The geological setting of the Greenhills Complex indicates an origin as a high-level magma chamber in a volcanic arc. Hornblende is abundant in all the high$\mathrm{Mg}$ dike rocks as a possible quenched phase, as a latemagmatic partial replacement of clinopyroxene, and as a late-magmatic groundmass and oikocrystic phase. It occurs in megacrystalline early dike-rocks and is ubiquitous throughout the gabbroic rocks of the Complex and the more evolved rocks in the remainder of the Bluff Peninsula, in some cases forming large oikocrysts. Its abundance testifies to an $\mathrm{H}_{2} \mathrm{O}$-rich melt, a signature of subduction-zone volcanism according to Gaetani et al.
(1993). Gaetani et al. demonstrated that the presence of $\mathrm{H}_{2} \mathrm{O}$ contents of $2-4 \mathrm{wt} \%$ at pressures of as little as 2 kbar, corresponding to $\sim 6 \mathrm{~km}$ depth, delays crystallization of plagioclase, and results in extended crystallization of olivine and clinopyroxene from ocean-island basaltic magmas. Early dunitic and wehrlitic cumulates may result, as in the Greenhills Complex. At the shallow depths envisaged, explosive eruptions from the magma chamber may be anticipated.

\section{Thermal history}

Application and interpretation of various geothermometers to these rocks are compromised by the extensive re-equilibration believed to have occurred during cooling in a water-rich environment. For an anhydrous liquid otherwise having the composition of the average monomineralic hornblende matrix in the interior of the Steep Head hornblende ankaramite dike, OU 25857 , olivine should first appear at about $1420^{\circ} \mathrm{C}$ (BVSP 1981). The estimated temperature would be increased if the initial liquid corresponded more closely to the bulkrock hornblende-plus-olivine composition, but would be reduced with increasing $\mathrm{H}_{2} \mathrm{O}$ content. The most magnesian composition observed in the phenocrysts is $\mathrm{Fo}_{92.7}$, in reasonable agreement with predicted $\sim$ Fo95. For the chilled margin of the same dike, OU 25853, the anhydrous saturation-surface should be reached at about $1400^{\circ} \mathrm{C}$, crystallizing olivine $\sim \mathrm{FO}_{94}$. Phenocrysts of less magnesian compositions, some zoned to $\mathrm{Fo}_{81.7}$, appear to be out of equilibrium with the inferred liquids. Similarly, observed compositions of $\mathrm{Fo}_{74.9-72.8}$ for olivine in the least magnesian of the high-Mg dikes studied, OU 54981, are discordant with a predicted $\mathrm{Fog}_{90}$ at about 1350 and $1290^{\circ} \mathrm{C}$ for anhydrous liquids corresponding, respectively, to the bulk-rock interior and marginal zones of this dike.

Use of the QUILF program (Frost \& Lindsley 1992) suggests a temperature of $989^{\circ} \mathrm{C}$ (D.H. Lindsley, pers. commun.) for an assemblage of forsterite - diopside enstatite - magnetite and fictive ilmenite in OU 30999 (23.89\% $\mathrm{MgO})$, with $f\left(\mathrm{O}_{2}\right)$ about $2.2 \mathrm{log}$ units above FMQ. This may represent a temperature during reaction with hornblende. The assemblage in dike OU 44996 $(16.84 \% \mathrm{MgO})$ gave a temperature of $1102^{\circ} \mathrm{C}$, suggestive of its solidus, with $f\left(\mathrm{O}_{2}\right)$ about $2 \log$ units above FMQ, but with evidence of Fe-Mg exchange which probably continued to lower temperatures.

Olivine-spinel thermometry for the olivinechromite pair OU 25857 (Table 2) and for three other pairs from the same rock suggests temperatures of $619^{\circ} \mathrm{C}, 635^{\circ} \mathrm{C}, 726^{\circ} \mathrm{C}$, and $780^{\circ} \mathrm{C}$ (A.A. Poustovetov, pers. commun.), using an equation that Poustovetov (1999) developed based on the approach of Sack \& Ghiorso (1991). This finding suggests major re-equilibration during cooling, and is compatible with the development of hornblende blebs and reactive exsolution in the associated diopside phenocrysts, and with incipi- 
ent exsolution of ilmenite from magnetite at about $645^{\circ} \mathrm{C}$ in a less $\mathrm{Mg}$-rich dike, as described above.

At the time the dikes were emplaced, the countryrock wehrlites had cooled sufficiently to allow brittle fracture and emplacement of dikes only 8-70 cm thick with sharply defined parallel walls. The interior of the magma chamber, $5 \mathrm{~km}$ in diameter, may still have been fluid, however. Although only $8 \mathrm{~cm}$ thick and sizegraded inward, dike rock OU 54981 cooled sufficiently slowly to yield a holocrystalline hornblende microgabbronorite, and although the very high-Mg dike, OU 25857, was rapidly quenched below its solidus, its subsequent cooling, and that of the other dikes, would have been slow.

We postulate initial emplacement of the dikes at about $1400^{\circ}$ to $1250^{\circ} \mathrm{C}$ depending upon their composition. Chilling to solidi of about $1100^{\circ} \mathrm{C}$ embraced crystallization of magmatic hornblende following that of enstatite. Subsequent cooling was slow as a result of the heat reservoir provided by the Greenhills Complex. Pyroxenes re-equilibrated to temperatures of $900-800^{\circ} \mathrm{C}$ or less, accompanied by the formation of hornblende blebs in diopside. Crystallization of postmagmatic hornblende with declining Al content, olivine-chromite reequilibration, and incipient exsolution of ilmenite continued to about $600^{\circ} \mathrm{C}$. Minor high-Si hornblende, chlorite, chrysotile, and other secondary minerals formed at still lower temperatures.

\section{Flow differentiation}

Two possible explanations, not mutually exclusive, must be considered for the contrasting composition of the selvedges and interiors of some of the dikes and the distribution of phenocrysts within them (Fig. 5). In the case of the picritic dikes of Skye, Harker (1904), reiterated by Bowen (1928, p. 158), considered "that a peridotitic liquid followed after the basaltic liquid, sweeping out the central portion of the partly consolidated doleritic dike". Bowen recognized that the basaltic liquid might itself have been interstitial to early crystals in the peridotitic magma and was squeezed off, penetrating into narrow fissures before being followed by the peridotitic portion of the magma as the fissures opened.

The composition of the aphanitic chilled margin of Steep Head dike OU 25853/7 indicates the existence of a melt with $17.4 \% \mathrm{MgO}$ on an anhydrous basis. The interior of this dike has $28.3 \% \mathrm{MgO}$ volatile-free, and consists essentially of phenocrysts of olivine and minor diopside in a monomineralic groundmass of hornblende that contains on average (anhydrous) 19\% MgO and that appears at least in part to be of quench origin. As some of the olivine phenocrysts are skeletal, at least some of the olivine must have crystallized from the melt that surrounded it. To flow along the center of the dike, the final melt contained more than $19 \% \mathrm{MgO}$ and was more $\mathrm{Mg}$-rich than the olivine-free melt that was quenched along the margin. However, the observed contents of
28.3, 26.0, and $24.2 \% \mathrm{MgO}$ in the interiors of dikes OU 25857, 44991, and 30999 almost certainly do not represent liquid compositions, and the abundant olivine and subordinate diopside phenocrysts in these rocks are considered to be in part accumulative and transported.

In the central portion of this and other dikes, the concentration of phenocrysts far exceeds the 5-8\% required, according to Komar (1972a, b), to create a physical differentiation within a flowing magma. This being the case, flowage differentiation, which by definition involves the mechanical redistribution of phenocrysts within a single liquid, must have occurred. The differentiation includes both number and size of grains, with a rapid fall-off toward the margins. Whereas individual exceptions may occur, derivation of the olivine phenocrysts from the immediate country-rock wehrlites is rejected, as discussed above. Their variable composition in the interiors of the more magnesian dikes is compatible with mixing of crystals derived from different sites in a magma chamber, as described by Marsh (1996). Furthermore, the presence of skeletal crystals of olivine suggests that some differentiation by crystal fractionation occurred within the dikes. Combined with the evidence for an overall more mafic melt phase in dike interiors compared with selvedges, a more complex process is indicated than was described by Gibb (1968, 1971) for the classic examples of flow differentiation in ultrabasic dikes of southwestern Skye.

\section{Reactive exsolution}

Oriented blebs of hornblende in clinopyroxene are interpreted as having formed under late-stage magmatic conditions, overlapping the temperature interval for exsolution of orthopyroxene lamellae, estimated as about $850^{\circ}-750^{\circ} \mathrm{C}$. This scenario suggests a process of reactive exsolution involving introduction of $\mathrm{K},(\mathrm{OH})$, and probably $\mathrm{Al}$ and $\mathrm{Na}$, while $\mathrm{Mg}, \mathrm{Fe}$, and $\mathrm{Cr}$ are preferentially partitioned from the clinopyroxene host into the hornblende blebs. Partitioning of $\mathrm{Ca}$ would leave the host relatively enriched in $\mathrm{Ca}$, as happens when orthopyroxene exsolves from diopside or augite. Reactive exsolution would be favored by the expanded field of clinopyroxene promoted by crystallization of $\mathrm{H}_{2} \mathrm{O}$ enriched basaltic melts.

\section{Dike emplacement in relation to magmatic evolution}

Mossman (1973) demonstrated that the Greenhills Complex consists of a layered series with basal dunite overlain by wehrlite, a transition zone of feldspathic wehrlite, and more than $600 \mathrm{~m}$ of gabbro (gabbronorite), with very calcic plagioclase $\left(\mathrm{An}_{91-88}\right)$. There is a layer of allivalite (gabbro consisting essentially of anorthite and olivine) in the gabbro zone, and minor late-stage trondhjemite. More evolved gabbronorite occurs within the immediate proximity, making up most of the remainder of Bluff Peninsula. Intrusion breccias attest to dis- 
turbances in the magma chamber, and reversals in cryptic layering suggest that fresh pulses of magma may have entered from time to time. Observed ranges of composition of olivine crystals in the layered series and in the ankaramitic dikes are shown in Figure 16. Olivine crystals in the feldspathic wehrlite cut by the Steep Head dike OU 25853/7 have compositions $\mathrm{Fo}_{75-73}$, whereas phenocrysts in the dike are in the range $\mathrm{F}_{93-}$ 82. This is close to the range recorded by Mossman (1973) for the dunites $\left(\mathrm{Fo}_{90-80}\right)$ and suggests that this late dike results from the entry of a fresh pulse of magma with $\mathrm{Mg} / \mathrm{Fe}$ approximating that from which the main layer of dunite had formed earlier as a cumulate. Dikes OU 44991 and 30999 have compositions of olivine phenocrysts compatible with crystallization from magma approximating that from which the dunites and wehrlites formed as cumulates, and the less magnesian dikes OU 44996, 54981, 54982 are interpreted as representing melts at similar stages of evolution to those from which the feldspathic wehrlites and the more mafic members of the layered gabbros had earlier formed.

\section{Effect of magmatic evolution on ankaramitic characteristics}

As shown in Figure 17, the ratio $\mathrm{CaO} / \mathrm{Al}_{2} \mathrm{O}_{3}$ drops in linear fashion as a function of the ratio $\mathrm{Mg} /(\mathrm{Mg}+\mathrm{Fe})$ in the high-Mg ankaramitic dikes. This coherent compositional trend is evidence that the dikes may be closely related genetically. Reconnaissance study of other late dikes (open circles in Fig. 17) shows that this trend is continued in low-alkali dikes of basaltic composition, with 9.13 to $3.37 \% \mathrm{MgO}$. The most Mg-rich example of these contains plentiful pseudomorphs of amphibole after phenocrystic clinopyroxene. Another member of

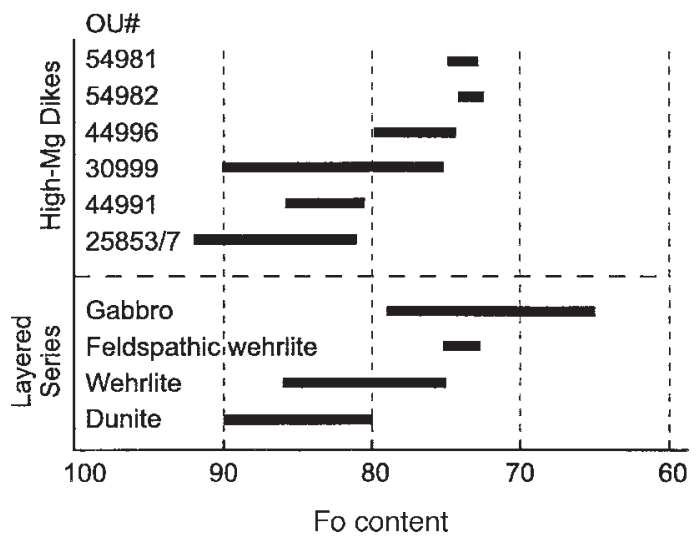

FIG. 16. Forsterite contents of olivine phenocrysts in the Greenhills high-Mg ankaramitic dikes and in the layered series of the Complex. Data for dunite, wehrlite, and gabbro from Mossman (1973). the suite is a micronorite, whereas the least magnesian of those plotted consists almost entirely of plagioclase and fine-grained hornblende, together with $3 \%$ biotite.

The initial liquids in the most Mg-rich dikes may have been undersaturated in diopside, and olivine crystallized in abundance as it also did in the main magma chamber in the upper crust to provide the dunite cumulates of the layered series. Once diopside appeared on the liquidus, its continuing crystallization together with olivine depleted the melts in $\mathrm{Ca}$ as well as in $\mathrm{Mg}$, reducing the $\mathrm{CaO} / \mathrm{Al}_{2} \mathrm{O}_{3}$ ratio in the melt. When plagioclase commenced to crystallize, it was extremely calcic $\left(\mathrm{An}_{99}\right.$ 89) and in small amount, thus having negligible effect on $\mathrm{CaO} / \mathrm{Al}_{2} \mathrm{O}_{3}$. Eventually, orthopyroxene and hornblende appeared on the liquidus, the orthopyroxene initially as a reaction rim on olivine, and later as independent crystals, as in the less extreme Mg-rich dikes. We conclude that primitive low-alkali arcankaramites can evolve into more normal arc-tholeiite compositions.

\section{Ankaramites in the Brook Street Terrane}

Ankaramites of early Permian age, including dikes, flows, and tuffs or breccias, are widespread in the Brook Street Terrane (Landis \& Waterhouse 1966, Williams \& Smith 1979, Sivell \& Rankin 1983, Ballard 1987). Common to all of these are abundant conspicuous green phenocrysts of chromian diopside. A relationship

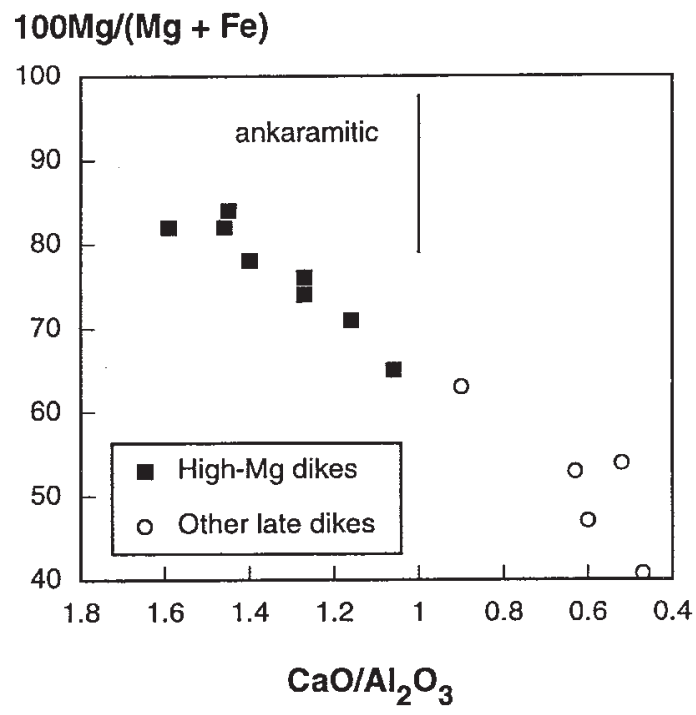

FIG. 17. Relationship between $\mathrm{CaO} / \mathrm{Al}_{2} \mathrm{O}_{3}$ and $100 \mathrm{Mg} /(\mathrm{Mg}$ $+\mathrm{Fe}$ ) for high-Mg and other late dikes, Greenhills Complex. According to Della-Pasqua \& Varne (1997), CaO/ $\mathrm{Al}_{2} \mathrm{O}_{3}$ (weight percent) greater than 1.00 is an indicator of ankaramitic affinities. 
between these ankaramites and the Greenhills Complex was suggested by Kimbrough et al. (1992). The present study confirms that primitive ankaramitic liquids existed within the Greenhills Complex, and they may be expected to have existed similarly in other dunite-wehrlite complexes intrusive into the Brook Street (Sivell \& Rankin 1983). Metabasaltic members of the Brook Street Terrane on D'Urville Island (Fig. 1) have primitive $R E E$ patterns only slightly enriched in light $R E E$ compared with the Greenhills ankaramitic dikes, as do ankaramites from the Eglinton Valley (Williams \& Smith 1979, and Fig. 13A). Multi-element distribution patterns of these metabasalts also appear to be closely analogous to those of the Greenhills dikes, if slightly more evolved.

We regard the Greenhills Complex as the upper-crust magma-chamber remnant of a volcano from which both ankaramites and more evolved low-K basaltic and perhaps andesitic products were erupted. Sivell \& Waterhouse (1988) have demonstrated similar geochemical characteristics in the Early Permian Gympie Group Volcanic Suite of southeastern Queensland, Australia. These volcanic rocks include coarse clinopyroxene-phyric ankaramites. Following other workers, Sivell \& Waterhouse (1988) interpreted the Gympie Group as a remnant of a major intra-oceanic volcanic arc, of which the Brook Street Volcanic Suite in New Zealand formed a part, and which was disrupted by the later opening of the Tasman Sea.

\section{Conclusions}

The high-Mg hornblende-bearing and other ankaramitic dikes were emplaced late in the sequence of events that generated the Greenhills Complex. This complex is the remnant of the upper-crust magma chamber of an island-arc volcano. Features of major- and minor-element composition, including low abundances of small, highly charged cations $(\mathrm{Nb}, \mathrm{Ta}, \mathrm{P}, \mathrm{Ti})$ and little-fractionated $R E E$ patterns, are typical of $\mathrm{H}_{2} \mathrm{O}$-rich low-K tholeiitic suites developed early in the history of island arcs. The dikes provide a model for magma evolution in the complex as a whole. Crystallization in the dikes, first of olivine, then joined by diopside, followed by anorthite and later enstatite, giving way to hornblende, parallels the development of dunite followed by wehrlite and feldspathic wehrlite cumulates in the layered series of the complex, followed by hornblende gabbronorites with highly calcic plagioclase. Reversals of cryptic layering in the layered series suggest the entry of fresh pulses of magma into the magma chamber, as do the late high- $\mathrm{Mg}$ dikes that cut rocks that had cooled sufficiently to undergo brittle fracture, and which, in some cases, have compositions more evolved than the dikes that cut them. The most highly magnesian dike-rocks, with up to $28 \% \mathrm{MgO}$, have olivine phenocrysts in excess of diopside, or are quenched to almost monomineralic hornblende. Nevertheless, they are ankaramitic rather than picritic in the sense of having $\mathrm{CaO} / \mathrm{Al}_{2} \mathrm{O}_{3}$ greater than one. Where the composition is somewhat more evolved, diopside phenocrysts exceed olivine, and progressive fractionation of these two minerals resulted in a falling $\mathrm{CaO} / \mathrm{Al}_{2} \mathrm{O}_{3}$ value. Once wholerock $\mathrm{MgO}$ contents dropped to about $10 \%, \mathrm{CaO} / \mathrm{Al}_{2} \mathrm{O}_{3}$ was no longer greater than one, the ankaramitic nature was lost, and evolution continued on an arc-tholeiitic to andesitic trend. Processes such as flow differentiation and reactive exsolution, which gave rise to oriented blebs of hornblende in diopside, contributed to the evolution of the dikes. Effusive ankaramitic and more evolved basaltic to andesitic breccias of comparable age in the same terrane provide evidence of explosive eruptions of $\mathrm{H}_{2} \mathrm{O}$-charged magma from this or similar magma chambers.

The dikes illustrate the chemical resemblance emphasized by Ernst (1987), of highly magnesian tholeiitic island-arc "picrites" and ankaramites to komatiites, but reveal significant differences. With their effusive analogues in the Brook Street Terrane, they provide another example of an increasingly recognized ankaramitic association in Phanerozoic island-arc systems.

\section{ACKNOWLEDGEMENTS}

This research has been supported by operating grant A8295 to D.J.M. from the Natural Sciences and Engineering Research Council of Canada, by research funding of coauthors (A.R., Y.K. and D.S.C.) from the University of Otago, and to D.S.C. from the New Zealand Foundation for Research, Science and Technology. The paper has been significantly improved as a result of reviews by D. Canil, G.T. Nixon, R. Varne, and the Editor. D. H. Lindsley (SUNY), P. Roeder and A. Poustovetov (Queen's University) have kindly generated geothermometric analyses and have contributed helpful discussion.We also gratefully acknowledge: analytical and much other assistance from R.D. Johnstone and D.J. Walls, the preparation of high-quality thin sections by J.M. Pillidge, specimens from J.M. Sinton, and helpful discussions with C.A. Landis (University of Otago), J.A. Gamble (Victoria University of Wellington), J.D. Greenough (Okanagan College, Kelowna, British Columbia), and C.M. Allen (Mount Allison University), help with diagrams by E. Ladley and the late K.P. Farrell. We thank A.J. Naldrett (University of Toronto) for constructive criticism of an earlier draft of the manuscript.

\section{REFERENCES}

Aitken, B.G. \& EcheverríA, L.M. (1984): Petrology and geochemistry of komatiites and tholeiites from Gorgona Island, Colombia. Contrib. Mineral. Petrol. 86, 94-105. 
ARAI, S. (1992): Chemistry of chromian spinel in volcanic rocks as a potential guide to magma chemistry. Mineral. Mag. 56, 173-184.

Arth, J.G., ARndt, N.T. \& NALDRETT, A.J. (1977): Genesis of Archean komatiites from Munro Township, Ontario: traceelement evidence. Geology 5, 590-594.

BALLARD, H.R. (1987): Tholeiitic arc-ankaramites in the Permian Brook Street Terrane: possible primary melts? Geol. Soc. N.Z. (Programme and Abstracts, Annual Conference, Dunedin), Misc. Publ. 3712.

BARSDell, M. (1988): Petrology and petrogenesis of clinopyroxene-rich tholeiitic lavas, Merelava Volcano, Vanuatu. J. Petrol. 29, 927-964.

\& BERRY, R.F. (1990): Origin and evolution of primitive island arc ankaramites from western Epi, Vanuatu. $J$. Petrol. 31, 747-777.

Basaltic Volcanism Study Project (1981): Characteristics of primary basaltic magmas. Basaltic volcanism on the terrestrial planets. Pergamon Press, Inc., New York, N.Y. (409-432).

BeARD, J.S. \& DAY, H.W. (1988): Petrology and emplacement of reversely zoned gabbro-diorite plutons in the Smartville Complex, northern California. J. Petrol. 29, 965-995.

Bence, A.E. \& Albee, A.L. (1968): Empirical correction factors for the electron microanalysis of silicates and oxides. J. Geol. 76, 382-403.

Bowen, N.L. (1928): The Evolution of the Igneous Rocks. Princeton University Press, Princeton, N.J.

Della-Pasqua, F.N. \& Varne, R. (1997): Primitive ankaramitic magmas in volcanic arcs: a melt-inclusion approach. Can. Mineral. 35, 291-312.

Donaldson, C.H. (1976): An experimental investigation of olivine morphology. Contrib. Mineral. Petrol. 57, 187-213.

Drever, H.I. \& Johnston, R. (1957): Crystal growth of forsteritic olivine in magmas and melts. Trans. R. Soc. Edinburgh 63, 289-314.

\& (1958): The petrology of picritic rocks in minor intrusions - a Hebridean group. Trans. R. Soc. Edinburgh 63, 459-497.

ERNST, W.G. (1987): Mafic meta-igneous arc rocks of apparent komatiitic affinities, Sawyers Bar area, central Klamath Mountains, northern California. In Magmatic Processes: Physicochemical Principles (B.O. Mysen, ed.). Geochem. Soc., Spec. Publ. 1, 191-208.

Frost, B.R. \& LindSLEY, D.H. (1992): Equilibria among FeTi oxides, pyroxene, olivine, and quartz. II. Application. Am. Mineral. 77, 1004-1020.

\& ANDERSEN, D.J. (1988): Fe-Ti oxide silicate equilibria: assemblages with fayalitic olivine. Am. Mineral. 73, 727-740.
Frost, C.D. \& CoOMBS, D.S. (1989): Nd isotope character of New Zealand sediments: implications for terrane concepts and crustal evolution. Am. J. Sci. 289, 744-770.

Gaetani, G.A., Grove, T.L. \& Bryan, W.B. (1993): The influence of water on the petrogenesis of subduction-related igneous rocks. Nature 365, 332-334.

GiBB, F.G.F. (1968): Flow differentiation in the xenolithic ultrabasic dykes of the Cuillins and the Strathaird Peninsula, Isle of Skye, Scotland. J. Petrol. 9, 411-443.

(1971): Crystal-liquid relationships in some ultrabasic dykes and their petrological significance. Contrib. Mineral. Petrol. 30, 103-118.

GIBSON, I.L. \& JAGAM, P. (1980): Instrumental neutron activation analysis of rocks and minerals. In Neutron Activation Analysis in the Geosciences (G.K. Muecke, ed.). Mineral. Assoc. Can., Short Course Handbook 5, 109-131.

Greenwood, R.C. \& Donaldson, C.H. (1989): The contact zone of the Rhum ultrabasic intrusion - new evidence for $\mathrm{MgO}$-rich magmas in the British Tertiary province. Terra 1(1), 169-170 (abstr.).

HARKer, A. (1904): The Tertiary igneous rocks of Skye. Geol. Surv. Scotland, Mem.

Helz, R.T. (1973): Phase relations of basalts in their melting range at $\mathrm{PH}_{2} \mathrm{O}=5 \mathrm{~kb}$ as a function of oxygen fugacity. $J$. Petrol. 14, 249-302.

Houghton, B.F. (1982): Low-grade metamorphism of the Takitimu Group, western Southland, New Zealand. N. Z. J. Geol. Geophys. 25, 1-19.

IRvinE, T.N. (1967): The Duke Island Ultramafic Complex, southeastern Alaska. In Ultramafic and Related Rocks (P.J. Wyllie, ed.). John Wiley \& Sons, New York, N.Y. (84-97).

JAHN, B.-M., GruAU, G. \& GLIKSON, A.Y. (1982): Komatiites of the Onverwacht Group, S. Africa: REE geochemistry, $\mathrm{Sm} / \mathrm{Nd}$ age and mantle evolution. Contrib. Mineral. Petrol. 80, 25-40.

Jurewicz, A.J.G. \& WATson, E.B. (1988): Cations in olivine. I. Calcium partitioning and calcium-magnesium distribution between olivines and coexisting melts, with petrologic applications. Contrib. Mineral. Petrol. 99, 176-185.

KaWACHI, Y. \& OKumuRa, K. (1978): Problems related to programme design for an automated electron microprobe analysis. Geol. Surv. Japan, Bull. 29, 27-43.

KENT, R.W. (1995): Magnesian basalts from the Hebrides, Scotland: chemical composition and relationship to the Icelandic plume. J. Geol. Soc. London 152, 979-983.

Kepezhinskas, P.K., TAYlor, R.N. \& Tanaka, H. (1993): Geochemistry of plutonic spinels from the North Kamchatka Arc: comparisons with spinels from other tectonic settings. Mineral. Mag. 57, 575-589. 
Kimbrough, D.L., Mattinson, J.M., Coombs, D.S., Landis, C.A. \& Johnston, M.R. (1992): Uranium-lead ages from the Dun Mountain ophiolite belt and Brook Street terrane, South Island, New Zealand. Geol. Soc. Am., Bull. 104, 429443.

, Tulloch, A.J., Geary, E., CoOmbs, D.S. \& LANDis, C.A. (1993): Isotopic ages from the Nelson region of South Island, New Zealand: crustal structure and definition of the Median Tectonic Zone. Tectonophys. 225, 433-448.

Komar, P.D. (1972a): Mechanical interactions of phenocrysts and flow differentiation of igneous dykes and sills. Geol. Soc. Am., Bull. 83, 973-988.

(1972b): Flow differentiation in igneous dikes and sills: profiles of velocity and phenocryst concentration. Geol. Soc. Am., Bull. 83, 3443-3448.

LANDis, C.A. \& WATERhouse, J.B. (1966): Discovery of Permian fossils in the Eglinton Volcanics, Southland. Trans. R. Soc. New Zealand, Geol. 4, 139-146.

LEAKE, B.E. AND 21 others (1997): Nomenclature of amphiboles: report of the Subcommittee on Amphiboles of the International Mineralogical Association, Commission on New Minerals and Mineral Names. Can. Mineral. 35, 219-246.

Le Maitre, R.W., ed. (1989): A Classification of Igneous Rocks and Glossary of Terms. Blackwell Scientific Publications, Oxford, U.K.

MARSH, B.D. (1996): Solidification fronts and magmatic evolution. Mineral. Mag. 60, 5-40.

Mossman, D.J. (1970): Fracture phenomena in and around serpentinized dunite in ultrabasic rocks from the Greenhills Complex, Southland, New Zealand. Geol. Soc. Am., Bull. 81, 3753-3756.

(1973): The geology of the Greenhills Ultramafic Complex, Bluff Peninsula, Southland, New Zealand. Geol. Soc. Am., Bull. 84, 39-62.

\& FORCE, L.M. (1969): Permian fossils from the Greenhills Group, Bluff, Southland, New Zealand. N. Z. J. Geol. Geophys. 12, 659-672.

NabeleK, P.I., Lindsley, D.H. \& Bohlen, S.R. (1987): Experimental examination of two-pyroxene graphical thermometers using natural pyroxenes with application to metaigneous pyroxenes from the Adirondack Mountains, New York. Contrib. Mineral. Petrol. 97, 66-71.

Nesbitt, R.W. \& Sun, Shen-Su (1976): Geochemistry of Archaean spinifex-textured peridotites and magnesian and low-magnesian tholeiites. Earth Planet. Sci. Lett. 31, 433-453.

\& Purvis, A.C. (1979): Komatiites: geochemistry and genesis. Can. Mineral. 17, 165-186.

Nisbet, E.G., Arndt, N.T., Bickle, M.J., Cameron, W.E., Chauvel, C., Cheadle, M., Hegner, E., Kyser, T.K., Martin, A., RenNer, R. \& RoEdDER, E. (1987): Uniquely fresh 2.7 Ga komatiites from the Belingwe greenstone belt, Zimbabwe. Geology 15, 1147-1150.

Pearce, J.A. (1983): Role of the sub-continental lithosphere in magma genesis at active continental margins. In Continental Basalts and Mantle Xenoliths (C.J. Hawkesworth \& M.J. Norry, eds.). Shiva Publishing Ltd., Nantwich, U.K. (230-249).

\& CANN, J.R. (1973): Tectonic setting of basic volcanic rocks determined using trace element analyses. Earth Planet. Sci Lett. 19, 290-300.

Poustovetov, A.A. (1999): Numerical Modeling of Chemical Equilibria between Chromian Spinel, Olivine, and Basaltic Melt, with Petrologic Applications. Ph.D. thesis, Queen's Univ., Kingston, Ontario, Canada.

Ramsay, W.R.H., Crawford, A.J. \& Foden, J.D. (1984): Field setting, mineralogy, chemistry and genesis of arc picrites, New Georgia, Solomon Islands. Contrib. Mineral. Petrol. 88, 386-402.

Russell, J.K. \& SNYDER, L.D. (1997): Petrology of picritic basalts from Kamloops, British Columbia: primary liquids from a Triassic-Jurassic arc. Can. Mineral. 35, 521-541.

SACK, R.O. \& GHIORSo, M.S. (1991): Chromian spinels as petrogenetic indicators: thermodynamics and petrological applications. Am. Mineral. 76, 827-847.

SERVICE, H. (1937): Intrusion of norite and the accompanying contact metamorphism at Bluff, New Zealand. Trans. $R$. Soc. N.Z. 67, 185-217.

Shervais, J.W. (1982): Ti-V plots and the petrogenesis of modern and ophiolitic lavas. Earth Planet. Sci. Lett. 59, 101-118.

Sivell, W. \& Rankin, P. (1983): Arc-tholeiite and ultramafic cumulate, Brook Street Volcanics, west D'Urville Island, New Zealand. N.Z. J. Geol. Geophys. 26, 239-257.

\& Waterhouse, J.B. (1988): Petrogenesis of Gympie Group volcanics: evidence for remnants of an early Permian volcanic arc in eastern Australia. Lithos 21, 8195.

Sun, Shen-Su \& McDonough, W.F. (1989): Chemical and isotopic systematics of oceanic basalts: implications for mantle composition and processes. In Magmatism in the Ocean Basins (A.D. Saunders \& M.J. Norry, eds.). Geol. Soc., Spec. Publ. 42, 313-345.

WiLliams, J.G. \& SMITH, I.E.M. (1979): Geochemical evidence for paired arcs in the Permian volcanics of southern New Zealand. Contrib. Mineral. Petrol. 68, 285-291.

Yoder, H.S., JR. \& TiLley, C.E. (1962): Origin of basalt magmas: an experimental study of natural and synthetic rock systems. J. Petrol. 3, 342-532.

Received November 23, 1998, revised manuscript accepted January 30, 2000. 